\title{
The Racial Other's Dancing Body in El milagro de anaquillé (1927): Avant-Garde Ballet and Ethnography of Afro-Cuban Performance
}

Lester Tomé

Smith College, ltome@smith.edu

Follow this and additional works at: https://scholarworks.smith.edu/dan_facpubs

Part of the Dance Commons

\section{Recommended Citation}

Tomé, Lester, "The Racial Other's Dancing Body in El milagro de anaquillé (1927): Avant-Garde Ballet and Ethnography of AfroCuban Performance" (2018). Dance: Faculty Publications, Smith College, Northampton, MA.

https://scholarworks.smith.edu/dan_facpubs/2 


\title{
The Racial Other's Dancing Body in El milagro de anaquillé (1927): Avant-Garde Ballet and Ethnography of Afro-Cuban Performance
}

Lester Tomé

Cuban Studies 47 (2018), 185-22

DOI: https://doi.org/10.1353/cub.2018.0010

\begin{abstract}
Note
This is a post-print version of the article, before copyediting. You can download the final, published version of the article from the website of Cuban Studies, or through the full-text database Project Muse. To quote from the article, please access the copyedited and formatted published version with page numbers.
\end{abstract}

\begin{abstract}
El milagro de anaquillé (1927), a ballet project with libretto by Alejo Carpentier and music by Amadeo Roldán, originated at the intersection of avant-garde art, afrocubanismo, and ethnography. Inspired by the aesthetic experimentation of Les Ballets Russes and Les Ballets Suédois in Europe, Carpentier and Roldán adopted ballet as a vehicle for introducing avant-garde trends in Cuba. Their work referenced two revolutionary ballets: Rite of Spring and, more importantly, Parade. Seeking to restage an Abakuá ritual, their project illustrated the artistic output of afrocubanismo as well as the movement's ethnographic approach to the study of black culture. The libretto, which depicted a conflict between a US filmmaker and a group of Abakuá celebrants, critiqued the colonialist caricatures of the racial other's dancing body in cinema and ballet. In doing so, it contributed to the concurrent repudiation of colonialist films in Latin American intellectual circles. Amid pivotal changes in cultural anthropology, the libretto also alluded to the ideological entanglement of anthropology and coloniality. It obliquely represented the lopsided interactions - mediated by class, race, and education — between ethnographers and subjects. In formulating such political messages, Milagro made adept use of caricature, irony, metatheatricality, nonrealist representation, and other techniques from the avant-garde tool kit for critical interrogation of reality.
\end{abstract}


In the gruesome closing scene of Alejo Carpentier's 1927 ballet libretto El milagro de anaquillé, two Afro-Cuban deities strangle a North American movie director who, in the process of filming an Abakuá ritual, has desecrated the altar. Directions for the mise en scène insist that the characters should look monstrous and move like robots. Carpentier imagines the divinities as gigantic puppets shaped like cylinders. The filmmaker is no less fantastic - wearing a mask that doubles the size of his head. ${ }^{1}$ These physiognomies, typical of Futurist Theater, make the avantgarde affiliation of the text apparent. In fact, the ballet was one of the earliest outcomes of the adoption of avant-garde vocabularies by Cuban artists in the 1920s. Meanwhile, the recreation of an Abakuá ceremony made the ballet one of the initial expressions of afrocubanismo, the groundbreaking movement that reclaimed the island's black traditions as an undeniable component of Cuban culture and incorporated them in the production of music, literature, and art of nationalist character. ${ }^{2}$ Carpentier and Amadeo Roldán, the composer of the ballet's score, researched Abakuá music, dance, and religion through direct observation in fieldwork. In this regard, their collaboration holds additional historical value as one of the earliest efforts in the modern ethnography of Afro-Cuban culture.

In the late 1920s, Cuban artists' espousal of avant-gardism expressed more than a desire to explore new aesthetic possibilities. These advocates of innovation aimed to transform society itself. They called for a revolution in education, the arts, politics, and the economy to overcome the handicaps that had frustrated the nation's development since the instauration of the Republic in 1902. Illustrating the intelligentsia's view that national renovation should take place on all fronts, in 1927 the Minorista Group called for improving the situation of the working classes, reforming public education, strengthening democracy and the electoral system, achieving political and economic autonomy from the US, and introducing in Cuba "the most recent doctrines, theories and practices in the sciences and the arts." ${ }^{33}$ Conceived that same year, Milagro epitomized two of the points from the Minorista Group's public declaration, to which Carpentier added his signature. In addition to proposing a cutting-edge spectacle up to date with international trends in avant-garde theater, the project delivered overt denunciation of US interventionism in Cuba. Carpentier dubbed Milagro an "anti-imperialist" ballet on account of the libretto's representation of the US filmmaker as an authoritarian intruder unwelcomed by the Cuban characters. ${ }^{4}$ The Afro-Cuban topic of the ballet amplified its political resonance. As Carpentier observed, the mere fact of showing serious interest in Afro-Cuban traditions, let along validating them as a source of nationalist art, was a confrontational gesture in a country where disenfranchisement of blacks and censure of their culture were the status quo. ${ }^{5}$

Rather than focusing on Milagro's statements against US interventionism and in favor of national recognition of Afro-Cuban culture, this article stresses other political implications of the ballet. Equally prominent in the libretto is the question of observing and representing the native subject through a colonialist gaze. Pointing his camera at characters from the Cuban countryside, the US filmmaker symbolized the proliferation of narratives depicting colonial and neocolonial bodies as exotic or savage in the expanding medium of cinema. Milagro lampooned the actions of the filmmaker and, through an ending that culminated in his fatal punishment, took a firm 
stance against the production of such discourse. Carpentier and Roldán also responded critically to the very same medium of ballet, whose own tradition of exotica had promoted similar objectification of non-European bodies and locales. In embracing a political theme and a caustic avant-garde vocabulary, Milagro negated the hedonistic exotica of the orientalist ballets that had been in vogue early in the century to, instead, affirm a revolutionary vision of this theatrical genre. Furthermore, Milagro's postcolonial perspective on the hegemonic observation of the subaltern other extended to the practice of ethnography, which, as noted above, was Carpentier and Roldán's method for gaining knowledge about Abakuá performances. ${ }^{6}$ As argued here, the libretto embedded a commentary on the problematic fieldwork interactions that arose as part of the ethnography of afrocubanismo when members of a predominantly white cultural elite studied the religious rituals of working-class blacks.

Before examining the ideological arguments brought to the fore by Milagro, this article considers a fundamental question: Why did Carpentier and Roldán, having no experience in the production of ballets and working in a country with no institutions in this medium, adopted the genre? I bring attention to how ballet, which in Europe had gained the status of a fashionable outcome for artistic innovation, afforded Carpentier and Roldán with an exciting vehicle for advancing the adoption of avant-garde art in Cuba and, simultaneously, showcasing black music, dance, and ritual as suitable materials for developing a nationalist theater. It was Carpentier's impressive familiarity with developments in modernist and avant-garde ballet, as contended here, that allow him to model Milagro upon works from the repertoire of Serge Diaghilev's Ballets Russes and Rolf de Maré's Ballets Suédois. ${ }^{7}$ In particular, I trace his inspiration for Milagro to Parade (1917), the iconoclastic product of the collaboration between Jean Cocteau, Pablo Picasso, Eric Satie, and Leonide Massine for Les Ballets Russes. Ballets like Parade revealed to Carpentier an arsenal of tools that could be used effectively in the articulation of political messages. Embracing the aesthetics of the avant-garde was a political declaration in itself: a disruption of the status quo, a non-conformist gesture in line with the revolutionary spirit of the Minorista Group. But, going beyond a general formulation of anti-establishment sentiment, Milagro was able to enounce a specific indictment of colonialist ideology by effectively manipulating the expressive potential of avant-garde ballet and Futurist Theater, with which it shared its attention to contemporary life, critical outlook of reality, broadening of choreographic sources, incorporation of popular entertainment, and juxtaposition of incongruous materials. In building a mordant satire of coloniality, the ballet also engaged subversive devices of avantgarde performance such as non-realist representation, caricature, and metatheatricality.

In arguing for the relevance of Milagro within the Cuban artistic corpus of this period and in connection to the politics of cinema, ballet, and ethnography, this article takes into consideration and adds to existing analyses of this piece by Frank Janney, who has examined it in his study of Carpentier's early works, and Vicky Unruh, who has paid consideration to it in her investigation of Latin American avant-garde production. Their interpretations of Milagro highlight a clash between modernity and tradition as the ballet's central theme. In Janney's view, the narrative is a parable of the triumph of the genuine culture and religious beliefs of Afro- 
Cubans over the power of capitalism and commercialism, symbolized by the US filmmaker. Along similar lines, but stressing the technological dimension of this conflict and its implications for art and performance, Unruh reads the libretto as a confrontation between commercial art based on mechanical reproduction, exemplified by cinema, and the socially transcendent, living performance that the Abakuá ritual represents. ${ }^{8}$ In different ways both scholars point out the significance of Milagro. Janney identifies in it seeds of the monumental novels that Carpentier would write later. Meanwhile, Unruh warns against assuming that a work like Milagro is too minor or unconventional to be relevant. This is because avant-gardism, being essentially experimental, manifested in a multifarious number of media and formats, often unorthodox. ${ }^{9}$ My case for the value of Milagro is consistent with her proposition that pieces like this one staged meaningful interventions in aesthetic, cultural, and social debates - even if by other standards ballet librettos may be considered an inconsequential literary subgenre. The truth is that the libretto did not constitute a rarity in the work of Carpentier. The piece was part of a group of seven different ballet projects envisioned by the writer around the same time. Those ballet projects, in turn, belong next to an assembly of ten other works from his early career, including poems, songs, an oratorio, an opera for puppets, and other musical pieces, in which he collaborated as a poet and librettist with Cuban and French composers. Authored between the late 1920s and the late 1930s, all these pieces fused elements of avant-garde art and Afro-Cuban folklore. ${ }^{10}$ Such output attests to how Carpentier regarded writing for the stage and the concert hall a substantive form of artistic expression and participation in the cultural trends of the era. This analysis of Milagro attempts to situate the work of one of Latin America's most important literary figures in new contexts. In view of Carpentier's investment in ballet, it seeks to provide a more detailed understanding of his connection to the medium, sources of balletic references, pioneering efforts to cultivate the genre in Cuba, and active involvement in what at the time was a pivotal international development in this art: the transition from exotica to avantgardism. The text also aims to illuminate Carpentier' engagement with avant-garde art as a method of cultural and political action. As Unruh observes, the Latin American avant-garde movement of which Carpentier was a participant might have emerged in close dialogue with European models, but it distinctively heeded the region's own cultural concerns and produced a thoughtful inquiry into the Latin American experience. ${ }^{11}$ Contributing to this argument, I define Milagro as Carpentier's intervention in a debate, unfolding in the 1920s, about colonialist representations of Latin Americans and other non-Western subjects in cinema - which sheds light on the writer's critical position toward the discourse of Western civilization and nonWestern barbarity. In ballet, a choreographic art, Carpentier found an ideal medium for creating a subversive parody of colonialist films since, as explained here, cinema's construction of savagery relied on Darwinist representations of dance, gesture, and human movement. The libretto appropriated and satirized the kinetic and narrative codes of barbarity on celluloid, while bringing attention to the staged, performative nature of exotica and primitivism.

Finally, in providing insight into Carpentier's anthropological study of Afro-Cuban culture, the case of Milagro permits to reassess his endeavors as an ethnographer and gain a 
more nuanced judgment of their worth. While the ethnographic activities of Carpentier's early career have been commonly disqualified as immature, problematic, and of limited value, studies by Anke Birkenmaier and Emily Maguire have contributed a deeper knowledge of not only the challenges but also merits of the writer's anthropological work. ${ }^{2}$ I aim to advance that discussion by highlighting the pioneer character of some of Carpentier's ethnographic methods. The very notion of attending Afro-Cuban ceremonials assiduously, as Carpentier did, was revolutionary at a time when rigorous fieldwork and participant observation were just beginning to claim the status of a scientific method. Also novel were his plans to stage an Abakuá ritual and feature knowledgeable Afro-Cuban dancers in it, which prefigured a performance-based approach to ethnography that would be realized by US anthropologists such as Zora Neale Hurston and Katherine Dunham in the 1930s. It is certain that Carpentier's ethnography of AfroCuban culture was ridden with the skewed power dynamic between a white intellectual in the role of anthropologists and marginalized blacks in the position of observed subjects. But, in Milagro, Carpentier seemed to acknowledge this critical limitation through an incipient form of ethnographic reflexivity, for, as argued here, the US filmmaker's violation of the Abakuá ritual symbolized the librettist's own interference with Afro-Cuban ceremonials during his preliminary fieldwork for the ballet. Moreover, his use of ethnography to develop a critique of Western misrepresentation of the racial other paralleled new anthropological approaches, as epitomized in the work of Franz Boas, that opposed the study of non-Western cultures from a Eurocentric perspective.

\section{Experiments in a Fashionable Medium: Ballet Librettos of Avant-Garde Inspiration}

Carpentier's attraction to the avant-garde movement in Europe, so clearly displayed in his journalism from the 1920s, holds they key to understanding his interest in producing ballets. Born in 1904, Carpentier initiated his literary career in 1922, at age eighteen, with contributions for magazines and newspapers in Havana. Already in 1923, the young author was writing frequent articles about Satie, Picasso, Cocteau, and other avant-garde artists for publications such as Chic, Social, and El Diario de la Marina ${ }^{13}$ His columns provided enthusiastic commentary about the freshest developments in music, painting, theater, and literature in Paris and other European cultural centers. Aiming to be more than a reporter of the avant-garde's latest tendencies, he co-organized two concerts of modernist music in Havana together with Roldánthe first one in 1926 and the second one the following year - and in this way became responsible for the first performances in Cuba of works by Igor Stravinsky, Claude Debussy, Maurice Ravel, Francis Poulenc, and Sergei Prokofiev. ${ }^{14}$ Additionally, Carpentier joined other local writers in founding Revista de Avance, a journal created with the purpose of informing about the artistic and intellectual trends of the day in Europe, Latin America, and also Cuba, where avant-garde art had begun to take roots. ${ }^{15}$ By then, some of the island's composers were starting to incorporate modernist techniques in their creations. Roldán and Alejandro García Caturla, the best exponents of this development, had studied the music of Poulenc, Darius Milhaud, and Manuel de Falla. ${ }^{16}$ 
At that same time, Cuban visual artists were advocating too for the adoption of revolutionary aesthetics. In 1927, painters Víctor Manuel and Antonio Gattorno, who had traveled to Paris to learn the Fauvist, Expressionist, Cubist, and Surrealist styles, presented the first local exhibitions of works that featured these new vocabularies. ${ }^{17}$

Being at the center of avant-gardism, ballet did not go unnoticed for a generation of Cuban artists emulating the novelties in European music and visual arts. In the years following the 1909 debut of Serge Diaghilev's Ballets Russes in Paris, ballet achieved a reputation for embodying the modernist and avant-garde aesthetics to which Cuban artists aspired. Diaghilev famously turned ballet into a medium for collaboration between revolutionary artists from various fields. The scores for Les Ballets Russes of Satie, Stravinsky, Poulenc, Milhaud, de Falla, and Prokofiev represented innovative developments in music. Similarly, the ballet décors and costumes of Picasso, Georges Braque, Henri Matisse, and Giorgio di Chirico, among other painters, embodied trends such as Cubism, Surrealism, and Constructivism. Keeping up with these novelties, the choreographers working for Diaghilev expanded the genre's stylistic range. As Lynn Garafola sustains, during and after World War I Les Ballets Russes assumed a style of performance linked to the tenets of Futurist Theater. Choreographers moved away from naturalist narratives and favored, instead, scenarios that incorporated discontinuity, synthesis, and depersonalization. At the same time, they loosened their adherence to the vocabulary of classical ballet to experiment with movement styles that stressed angularity and mechanization, or that borrowed elements from circus, sports, and popular entertainment. ${ }^{18}$ In Les Noces (1923), for example, Bronislava Nijinska staged a villagers' wedding using stark mechanistic motions that made the characters look like automatons. Meanwhile, in Massine's Pas d'acier (1927) the dancers manipulated hammers, levers, and pulleys in an ode to labor in the industrial age. These developments marked a radical departure from prewar works by Les Ballet Russes such as Cléopâtre (1909), Schéhérazade (1910), and Le Dieu Bleu (1912), which, as explained later in this article, had been choreographed in an orientalist vein and followed conventional narratives and means of representation.

During a childhood trip to Paris in 1913, Carpentier had enjoyed the opportunity to witness a rehearsal of Les Ballets Russes's Firebird (1910), a Russian folktale featuring music by Stravinsky, choreography by Mikhail Fokine, and designs by Léon Bakst. Later, he had seen presentations in Havana of Ana Pavlova, who visited Cuba several times between 1915 and 1919. But neither Firebird nor Pavlova embodied avant-garde ballet_Fokine's work belonged to Les Ballets Russes's more conventional repertoire and Pavlova's performances reflected her traditionalist stance of opposition to experimentation. ${ }^{19}$ While these early encounters with ballet planted the seeds of Carpentier's love of the medium, it was by reading about it that he was drawn to the avant-gardist expressions of this art form. He kept abreast of events in European ballet through French publications on modern art that arrived to Havana. ${ }^{20}$ Not only did he read those magazines with devotion, but, also, he used them as sources for his own second-hand reports on Les Ballets Russes's seasons, as illustrated by a 1923 piece for La Discusión in which he wrote excitedly about Les Noces within just one month of its premiere in Paris. ${ }^{21}$ His 
increasing fascination with ballet became evident the following year in a series of articles for Chic in which he discussed contributions to the genre by Stravinsky, Ravel, Satie, and Picasso. ${ }^{22}$ In another sign of enthusiasm for the medium, he and Roldán ordered ballet scores from abroad and studied them in detail, as was the case with Stravinsky's Rite of Spring. ${ }^{23}$

Soon after, Carpentier and Roldán sought to follow in the footsteps of the modernist and avant-garde artists who had made ballet a cutting-edge genre. If for Roldán ballet was a vehicle for musical experimentation, for Carpentier it represented a literary outlet that permitted its own measure of originality. In the mid 1920s, having published only his articles for newspapers and magazines - and very far yet from becoming the prominent novelist recognized with the Cervantes Award in 1977 and nominated for the Nobel Prize in 1979-Carpentier was eager to participate in the artistic life of the time as more than a journalist. ${ }^{24}$ Writing scenarios for a stimulating form of spectacle would enable him to express his own creative voice. In spite of librettos not carrying the greatest literary weight, in Europe respected figures were authoring and legitimizing them as a dramatic subgenre. From 1920 to 1925, Rolf de Maré's Ballets Suédois staged productions in which the librettos by Cocteau, Paul Claudel, Blaise Cendrars, and Luigi Pirandello featured prominently. The scenarios went from representing aspects of contemporary life to depicting surrealist environments. The significance of literary material was the most evident in Cocteau's Les mariés de la Tour Eiffel (1921), a work that mixed dance and spoken drama. ${ }^{25}$ Conscious of the literary potential of librettos, Carpentier equated avant-garde ballet to a form of plastic, dramatic or choreographic poetry in chronicles in which he gave consideration to the work of the librettist. In a 1923 article about Les Ballets Suédois's L'Homme et son désir (1921), he declared that Claudel's libretto for this spectacle was among the author's most original creations. He highlighted the producers' classification of the ballet as a "poème plastique." The following year, Carpentier judged that the most significant work of that troupe's season had been La Jarre (1924), a choreographic satire conceived by Pirandello. Similarly, in an extensive 1925 essay about Cocteau, he explained how the author's signature "aesthetic of the common place" had come to life masterfully in Les mariés de la Tour Eiffel and the "surrealist choreographic poem" Parade. ${ }^{26}$

Performances in Havana of the theatre troupe of Duvan Torzov, in 1924, catalyzed Carpentier's interest in writing for the stage. Witnessing Torzov's production of the revue $L a$ Chauve-Sauris, he came the closest to experiencing first hand the innovative theatrical spectacles being conceived in Europe. The revue's revolutionary elements triggered his excitement. He lauded the production as a form of total theatre that integrated words, music, and décors into an expressive gesamtkunstwerk. His description of the performance pointed to qualities of synthesis and dynamism typical of Filippo Tommaso Marinetti's concept of Futurist Theatre. Proposing Torzov's piece as a model for a "Cuban synthetic theater," Carpentier prompted local artists to cultivate what would be a "completely new art" in the country. He called them to coopt the aesthetic elements of avant-garde spectacles. The novel Cuban productions, as recommended by him, would fall within a collaborative template by incorporating music, dance, visual arts, and literary ideas, while adhering to the premises of directedness, distillation, dynamism, originality, 
and economy of means. ${ }^{27}$ Going further, he identified potential themes in Cuban colonial history and folklore, as captured in the nineteenth-century drawings of Víctor Patricio de Landaluze and Frédéric Mialhe - an approach that, in fact, he would follow in La rebambaramba, the first of his own ballet librettos.

Not long after issuing this call for developing a Cuban experimental theatre, Carpentier approached local composers and designers with the purpose of interesting them in producing ballets. In a letter to García Caturla from March $15^{\text {th }}, 1927$, he expressed eagerness to collaborate with him: "For a while I have been obsessed with the idea of finally outlining three or four scenarios of Cuban ballets, to subject them to your judgment and Roldán's." ${ }^{28}$ Noteworthy is the fact that by this point Carpentier had already engaged Roldán in plans for a ballet. The previous year, they had begun work on La rebambaramba. ${ }^{29}$ Its comedic libretto, set in colonial Havana, presents the competition of three suitors - a clumsy soldier, a clever free black, and a jealous coachman - for the love of the beautiful mulata Mercé. The narrative takes place against the backdrop of Three Kings' Day carnival, when, according to colonial tradition, slaves paraded their dances on the streets of the city. ${ }^{30}$ Caricaturist José Hurtado de Mendoza was brought onboard as the designer of sets and costumes. Throughout 1927 Carpentier worked on other ballet projects, including Milagro, again in collaboration with Roldán and Hurtado de Mendoza. He also invited García Caturla to compose music for a ballet depicting the entrance of an itinerant circus to a Cuban provincial town, with the action revolving around the colorful cortege of musicians, clowns, and elephants that march on the streets to announce the circus's arrival. ${ }^{31}$ Three other ballet projects from this period are more difficult to date with precision. Carpentier undertook them before marching to Paris in self-exile in March 1928, but there is no documentation establishing the exact year of each one's conception. Among them was La hija del ogro (The Ogre's Daughter), in association with Roldán and painter Adia Yunkers. In this farce, a girl elopes with her beau from the castle of her father, who is an ogre. The monster chases them as they come across a travelling circus and, later, a movie set where Charles Chaplin comes to the lovers' rescue. ${ }^{32}$ Moreover, Carpentier entertained plans for a ballet titled Azúcar (Sugar), which would "express, by means of a dynamic performance, the convulsive life of the sugar mill, the labor of the men, and the blind activity of the machines."33 Less is known about his ideas for Mata-Cangrejo (Crab-Killer), another ballet project attributed to this period. ${ }^{34}$ The correspondence between Carpentier and García Caturla reveals plans for yet another ballet, $E l$ embó, whose title refers to an Afro-Cuban funerary ritual. ${ }^{35}$

In summary, within the span of a few years Carpentier envisaged seven ballet projects. ${ }^{36}$ Based on the records preserved to date, he completed the librettos for three of them: $L a$ rebambaramba and Milagro (for both of which Roldán finalized the music), and La hija del ogro (which, in contrast, did not originate a score). Judged on their own terms, these texts show Carpentier's surprising mastery of the ballet libretto as a literary subgenre with its own possibilities and challenges. As he explained to García Caturla, a librettist had to bear in mind the imperatives of the theatrical spectacle as a whole. Accordingly, the writer saw himself in a procreant role that influenced all aspects of the production. Finding an appropriate subject was 
not sufficient: the plot had to lend itself to stylized choreographic representation, spark the imagination of the painter in charge of sets and costumes, and contain actions and environments befitting to inspired musicalization. For this reason, he explained that even if a libretto could be distilled into "fifty lines," it had to encapsulate "the true quintessence of many ideas." 37 The scenarios for La rebambaramba and Milagro did justice to this complex task. They introduced vivid characters, picturesque backdrops, and narratives conducive to the showcase of music and dance. Well-developed concepts animated each ballet, which sought to provide both entertainment and social commentary. For instance, La rebambaramba dazzles with its colorful depiction of carnival in Havana, while, in the subversive tradition of Cuban teatro bufo, it indicts patriarchal, racist and colonialist ideology in nineteenth-century Cuba. ${ }^{38}$ In addition to creating rich content and attending to the multiple requirements of a theatrical production, Carpentier succeeded at infusing his ballets with "a high level of Cubanness" while capturing "the esprit of the day" - a quest to package national character in avant-garde form that he shared with other Cuban artists of his generation. ${ }^{39}$

None of these works reached the stage at the time, at least not in choreographic form. Orchestral suites of La rebambaramba and Milagro premiered in symphonic concerts in Havana on August $12^{\text {th }}, 1928$, and September $22^{\text {nd }}, 1929$, respectively. But the absence of dance ensembles in Cuba rendered the choreographic productions unfeasible. Nevertheless, the librettos and scores hold historical significance as pioneer efforts to produce ballets locally (although visiting European dancers had presented ballet in Cuba since the nineteenth century, no Cuban ballets had ever been created). Three decades later, choreographers Alberto Alonso and Ramiro Guerra would finally stage La rebambaramba and Milagro, but their productions, which did not engage Carpentier in direct collaboration and reflected the artistic climate of a different period, are not considered in the present discussion. ${ }^{40}$

\section{Critical Interpretations of Contemporary Life in Avant-Garde Ballet: From Parade to Milagro}

In parallel to presenting distinctively Cuban content, Milagro's amalgamation of Expressionist, Cubist, Futurist, and Surrealist traits revealed Carpentier and Roldán's desire to exhaust the possibilities of avant-garde art. More specifically, Milagro evidenced a dialogue with the revolutionary dance aesthetics modeled by Les Ballets Russes and Les Ballet Suédois. The Abakuá ceremony referenced Rite of Spring (1913), the legendary ballet with music by Stravinsky, choreography by Vaslav Nijinsky, and designs by Nicholas Roerich that had scandalized Paris with its irreverent recreation of an ancient sacrificial ritual in pagan Russia. Not only did Rite of Spring provide an antecedent for centering a ballet narrative on the theme of ritual; it also led Carpentier and Roldán to engage with Afro-Cuban culture through a modernist sensibility. Their acquired Stravinskian perspective on rhythm pushed them to listen to the island's black music with fresh ears, while growing aware of its sophistication. The writer reasoned that the polyrhythmic richness that had made Stravinsky's composition so 
revolutionary already existed, in an even superior manifestation, in Afro-Cuban music. For Carpentier, thus, black musical traditions were ripe for being repackaged as innovative products. ${ }^{41}$ Consistently, Roldán's score for Milagro integrated Afro-Cuban sources and progressive composition techniques. Carpentier's description of this music suggested a strong parallel with the harsh sonority of Rite of Spring. "Nothing in it sought to caress or seduce the listener," he indicated. Harmonically, it was "one of Roldán's severest scores," creating the effect of a sonic environment "angular and linear, [in the] color of steel, with no trace of flattery.",42

The influence of Rite of Spring on Carpentier is not surprising to those familiar with his oeuvre. His final novel, La consagración de la primavera (1978), borrowed its title from the iconic ballet - the novel's main character, a Russian ballerina, arrives to Cuba after having danced with Les Ballets Russes and, not unlike Carpentier himself with Milagro, stages a singular production of Nijinky's ballet with Afro-Cuban dancers. Yet, another of Les Ballets Russes's works, Parade, was more fundamentally influential in the conception of Milagro. Parade's premiere in 1917 had ushered a new era in ballet, as Carpentier noted in an article from 1929 about the aesthetic evolution of Les Ballets Russes. ${ }^{43}$ While some of the early modernist productions of Diaghilev's troupe had spoken in the languages of Primitivism, Neo-Romanticism and Symbolism, Parade established ballet's adoption of even more innovative trends. Carpentier had paid special attention to Parade in various columns that predated his work on Milagro. His chronicles from 1924 repeatedly characterized that ballet as an example of Satie's, Picasso's, and Cocteau's innovations. One of those texts explained that Parade embodied a new musical aesthetics in which simple melodies wedded daring harmonic effects. Another essay, about the rise of Cubism, indicated that Picasso's designs for the ballet were deservingly notable. ${ }^{44}$ Yet another article, concerned with Futurist art, rightly observed that Parade had been a realist attempt to capture the street life of Paris in all its banality. ${ }^{45}$ This comment demonstrated familiarity with the producers' original vision; an essay by Guillaume Apollinaire in the souvenir program for the premiere of Parade had explained the multiple elements of the piece precisely in terms of their realist function. ${ }^{46}$

Cocteau's libretto for Parade introduced a theater-within-a-theater scenario, a metatheatrical situation in which the spectators contemplated the performers in the act of performing not for them but for other spectators - an imaginary street crowd. A magician, a mime, acrobats, and a cheval jupon (two clowns disguised as one horse) perform on the street, trying in vane to entice onlookers to enter the auditorium where they are about to present a variety show (a show that Parade does not depict in the end). Interspersed with their dances are the numbers of two greedy managers who advertise the show with grandiloquence that betrays the banality of the planned music-hall event. The actions on the stage cited lowbrow attractions that the audience could recognize from films, variety acts, and circus and magic shows playing in Paris at the time. Cocteau's ironic look at these popular entertainment genres celebrated their commonplace poetry while exposing their tackiness and commercialism. The emphasis was on the mundane occurrences, apathetic encounters, and vacuous publicity that defined the city's 
street life. Salient among the ballet's most spectacular elements were the managers' costumes, which Picasso designed in the shape of enormous contraptions akin to three-dimensional Cubistcollages (Fig. 1). Satie's score, of Surrealist and Futurist orientation, was equally memorable for blending such disparate ingredients as classical music, a jazz number, and the everyday noises of modern machinery (typewriters, telegraphs, sirens, engines, klaxons). Meanwhile, the choreography borrowed heavily from popular entertainment, as it was most evident in the dance of the Little American Girl. Her pantomime reproduced actions and gestures from silent filmsmovements that, in the context of a ballet, exhibited the Surrealist quality of a familiar object placed in an unfamiliar environment. ${ }^{47}$

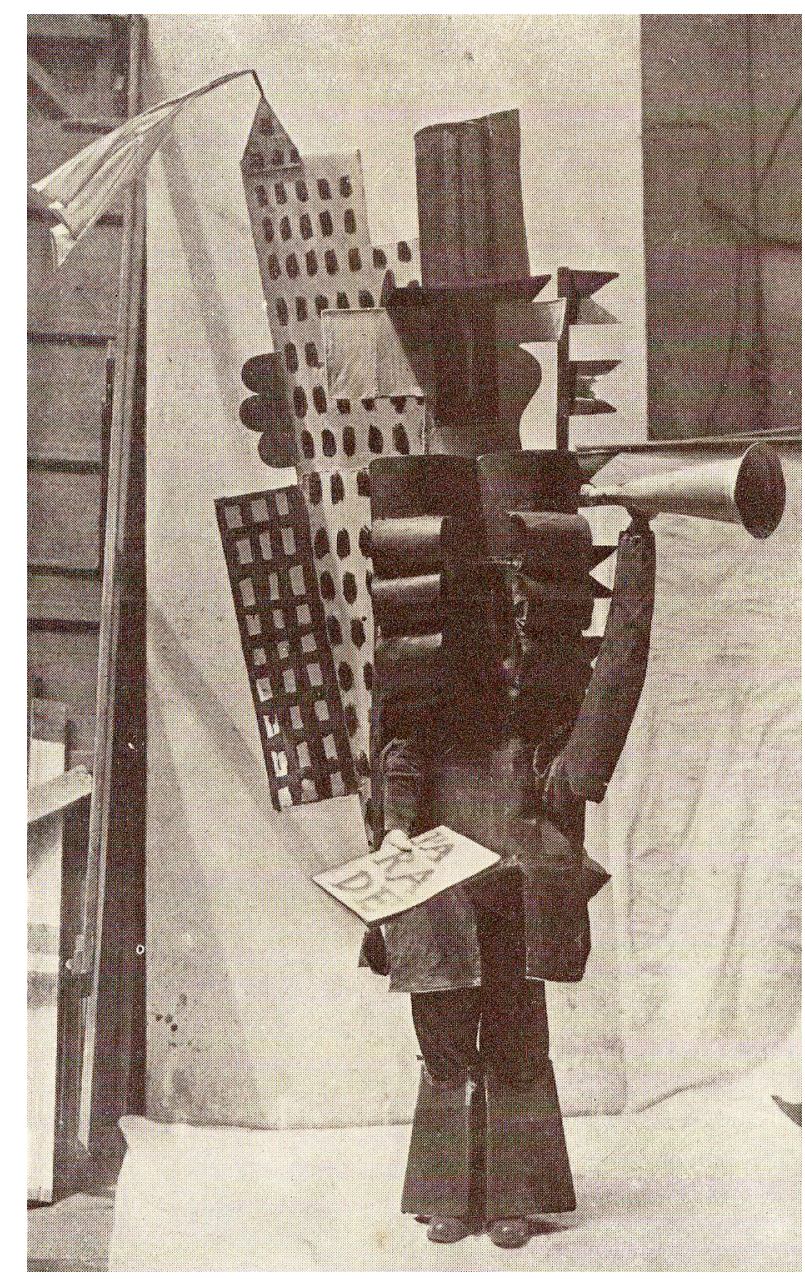

In paying attention to the life of the times, Parade broadened the range of ballet's subject matter and inaugurated a trend that inspired various works of Les Ballets Russes and became the hallmark of Les Ballets Suédois's productions. ${ }^{48}$ Until then, ballet had been concerned with romantic, exotic, or mythical subjects, while embodying autocratic and bourgeois ideologies. In groundbreaking fashion, Parade departed from that model of narrative to convey, instead, a nonconformist perspective on modern life and its alienating values. Cocteau's music hall managers, depicted as deceitful automatons driven by a desire to profit, both epitomized and 
denounced the soullessness of capitalism. In the original libretto, the French Manager beckoned passersby to buy tickets with empty promises to change their equally empty lives: "If you want to become rich - if you feel sick - if you have attacks for languor - ENTER [...] Boredom is lying in wait for you! You are sleeping without being aware of it! Wake up! Enter, enter!" Similarly, Parade's American Manager advertised the show as the solution for the crowd to alter their apathetic experience of life: "IT IS A CRIME to kill your own curiosity [...] Are you dead? NO? Then you must LIVE! Make sure you get this idea through your head! A timid man is a DEAD man." 49

Just as Parade took its inspiration from the contemporary, Milagro rendered a picture of the present. To do so, it relied on similar signifiers of a dynamic modernity. Parade's imagery of skyscrapers, machinery, cinema, and jazz was ingeniously recontextualized in Milagro's setting, in which each of these elements reappeared (as detailed in the analysis of the libretto that follows below). But Milagro's own depiction of the present extended beyond a Futurist display of the accouterments of twentieth-century architecture, technology, and popular entertainment. The notion that ballet could question the status quo in contemporary life, as originated in Parade, paved the way for Carpentier to utilize this genre as a means of social and cultural critique. In this regard, Carpentier epitomized the Latin American artists' interest in turning avant-garde artistic production into a platform for reflecting critically on the social and cultural issues of their nations.

The setting of Milagro's narrative in a sugarcane plantation immediately establishes the ballet's Cuban character and references sugar production as the backbone of the country's economy. The view of a sugarcane field, palm trees, and rural huts, elements all contemplated in Carpentier's indications for the décors, celebrate fixtures of the island's rural landscape. Types easily recognizable as local conform the majority of the dramatis personae and reinforce the national specificity of the work: sugarcane cutters, guajiros (Cuban peasants), and, as part of the Abakuá ritual, an iyamba (priest) and a diablito (ireme ceremonial dancer). The music and dance numbers consolidate the ballet's nationalist flavor. In contrasting a Spanish-derived zapateo and the eminently African Abakuá ceremonial, the libretto showcases the broad spectrum of Cuban culture and makes a statement about its hybrid roots - as such, it prefigures Carpentier's meticulous analysis of the country's European and African musical genealogies in his seminal treatise La música en Cuba (1946).

Milagro's storyline revolves around a US filmmaker (the Business Man) determined to make a movie in the Cuban countryside. He travels with two fellow North Americans (the Flapper and the Sailor) whom he employs as actors. First, he films them in an improvised toreador scene, surrounded by a group of Cuban peasants. Later, he attempts to shoot an illconcocted Tarzanesque sequence with the two actors appearing against the backdrop of an unfolding Afro-Cuban ritual. Rather than undermining the Cubanness of the ballet, the presence of these three North American figures suggests the political reality of a country subject to US interventionism. Presiding over the stage, the silhouette of a sugar mill acts as a reminder of the North American control of the island's economy, while the doings of the Business Man, a self- 
interested bully, constitute an allegory of the authoritarian and exploitative North American actions in the country.

Before further discussing other ways in which Milagro interrogates contemporary reality and formulates a critique of coloniality, it is essential to review its narrative in detail, which provides an opportunity for establishing the libretto's aesthetic affiliation to avant-garde art and performance. That affiliation often manifests in the form of a stylistic debt to Parade. Milagro borrows from that ballet's themes and imagery while incorporating avant-gardism's favored devices of absurdity, hyperbole, juxtaposition, caricature, grotesquerie, satire, and metatheatricality. The libretto's indications for the mise en scéne include clear directions for realizing the experimental set, costumes, and choreography along that line. The set's most prominent features would have been the Peasant's and the Iyamba's huts, in the style of the rudimentary dwellings typical of the Cuban countryside. However, those conventional buildings were expected to appear against a backdrop in which lines and planes intersected with the geometric quality of an avant-garde design. Like a "vegetable fence," the uniform sugarcane field would have extended across the stage, forming a horizontal band of green interrupted by the vertical lines of equidistant palm trees. Proclaiming the Futurist love of industrial motifs, the "geometric hulk" of a sugar mill was supposed to dominate the horizon. Carpentier imagined its three, "very exaggerated" chimneys shooting upward into the theater's ceiling as disproportionate columns that contributed an Expressionist accent. Thick black letters would have covered the chimneys, introducing the sort of typographic element popular in Cubism. An equally avant-garde sensibility informs Carpentier's suggestions for the costumes and choreography. The Business Man and the Twins (two Afro-Cuban deities) would have appeared in masks, looking "unreal and monstrous," and dancing "like automatons." Such masked, grotesque, robotic characters were the currency of Futurism, which jettisoned psychological drama in favor of a theater of impersonality and automatism. A mechanistic style would have marked, too, the demeanor of the eight Sugarcane Cutters, who were called to perform with "perfect synchronicity, executing the same gestures simultaneously." Speed, another of Futurism's fixations, would have defined the dancing of the Sailor, the Flapper, and the Diablito, characters all directed to display a "frenetic rhythm." As other avant-garde ballets, the libretto projects a hotchpotch of dance styles: a Cuban zapateo, a jazz number, a Spanish dance pastiche, and Afro-Cuban dances.

The one-act libretto unfolds swiftly in eight short scenes. As the narrative progresses, an atmosphere of Surrealist absurdity congeals out of incongruous juxtapositions that take place at every turn - industry and countryside, foreign and local characters, a skyscraper and rustic huts, jazz and Cuban music, commercial cinema and religious ritual.

The ballet opens with the Peasant's return to his hut after a day of work. He pushes a wheeled toy horse that succumbs under disproportionally large saddlebags (the reappearance of disproportionate objects throughout the libretto creates an Expressionist effect). With the day's work done, the Peasant begins to plays the guitar. A group of farmers assemble and perform the zapateo, a feet-stomping dance that epitomizes Cuban rural culture. Just at this point, the 
Business Man enters the stage under the form of an accretion of artifacts that obscure his human shape. He wears an enormous cap and a mask twice the size of his head, and carries strange signs, a bicycle air pump, a film camera, a tripod, and extravagant parcels all at once. (The Business Man, like the two Managers of Parade, is defined as a profiteering entrepreneur by its very name, and he is, like one of the Managers, an American. His dehumanized, monstrous figure also hints at Parade's Managers, who wore ten-feet tall Cubist constructions that integrated disparate articles [Fig. 1]. The collage-like American Manager, for instance, donned a gigantic top hat; had a skyscraper, a cloud, and flags attached to his back; and carried a megaphone and a placard.) The peasants, intimidated by the Business Man's appearance, stop dancing.

The Business Man surveys the grounds as the potential location for a movie. He feels the muscles of the peasants as if they were livestock. Satisfied, he approaches the fore and shouts: "OK!" The interjection triggers a "rhythmic explosion" of jazz music. (What follows resembles Parade's jazz number, in which the character known as the American Girl performed a hectic pantomime allusive of silent films' actions. In full-speed motion, she moved across the stage as if riding a horse, assaulting a train, playing Cowboys and Indians, cranking up a car, pedaling a bike, taking photographs, sailing in a boat, swimming, dancing a ragtime, impersonating Charlie Chaplin, and so on. Along similar lines, Carpentier imagines Milagro's jazz scene as a number in which American types flood the stage with frenzied and disjointed commotion, evoking the world of cinema, and introducing American iconography.) The "Yankee" Sailor and the Flapper, amateurish actors of the planned movie, enter the stage dancing an inarticulate, fast-paced black bottom. While they dance, the Business Man gets himself busy with the "furious activity" of transforming the location into a movie set. He attaches flashy signs in English to the Iyamba's hut. They read, "Bar," "Ice Cream Soda," and "Wrigley Chewing Gum." In the process, he covers an icon of St. Lazarus that presides over the hut. ${ }^{50}$ Somewhere else he hangs another sign: "Church of the Rotarian Church." Next, he operates an air pump to make an inflatable skyscraper grow rapidly out of the sugar cane field (yet another connection to Parade's American Manager, whose most distinguishable feature was the skyscraper protruding from his back). The air pump explodes on the final note of the black bottom.

After readying the set, the Business Man continues his frantic work. He mounts the camera on its tripod and hands Spanish costumes and props to the actors: decorative comb, mantilla, and shawl for the Flapper, and toreador's flag, cape, and cap for the Sailor. Next he gives tambourines to the stupefied peasants, engaging them as extras with no consultation. The shooting begins: surrounded by a circle of tambourine-playing peasants, the American duo performs a grotesque Spanish dance that mimics a bullfight. By the duet's end, the Flapper-Bull kneels in an imploring gesture at the feet of the Soldier-Toreador, who threatens to kill her with a sword. (By then, it has become clear that Milagro shares Parade's scorn of the crassness, amateurism, and commercialism of certain forms of popular entertainment, cinema in this case.)

As the filming of the pseudo-Spanish scene is about to come to an end, the Iyamba and a group of black sugarcane cutters arrive from the fields. They ruin the shooting by walking in 
front of the camera. Enraged, the Business Man throws a fit, but the black workers pay him no heed. Founding his hut covered with signs in English, the Iyamba takes them down and throws them off stage. He restores the image of St. Lazarus. The Business Man tries to protest but a chilling look from the Iyamba keeps him at bay.

Soon after this, the Iyamba begins preparations for a ritual by setting a number of ceremonial objects on a bench. The black men form a circle around the bench and crouch, with knees and elbows touching the ground. The Diablito, an officiating masked figure, comes out of the hut dancing energetically (Fig. 2). He jumps over the prostrated men while running a black rooster along their backs. Next, the Diablito places a pot with the ritual meal in the center of the circle. He spreads gunpowder around it. As the powder burns, he dances over the red flames and around the pot. The worshippers join in the ritual. They try to reach the pot, but the Diablito guards it furiously. After several attempts, one of the men jumps into the center of the circle and runs away with the pot. The Diablito pursues him in a ceremonial dance.

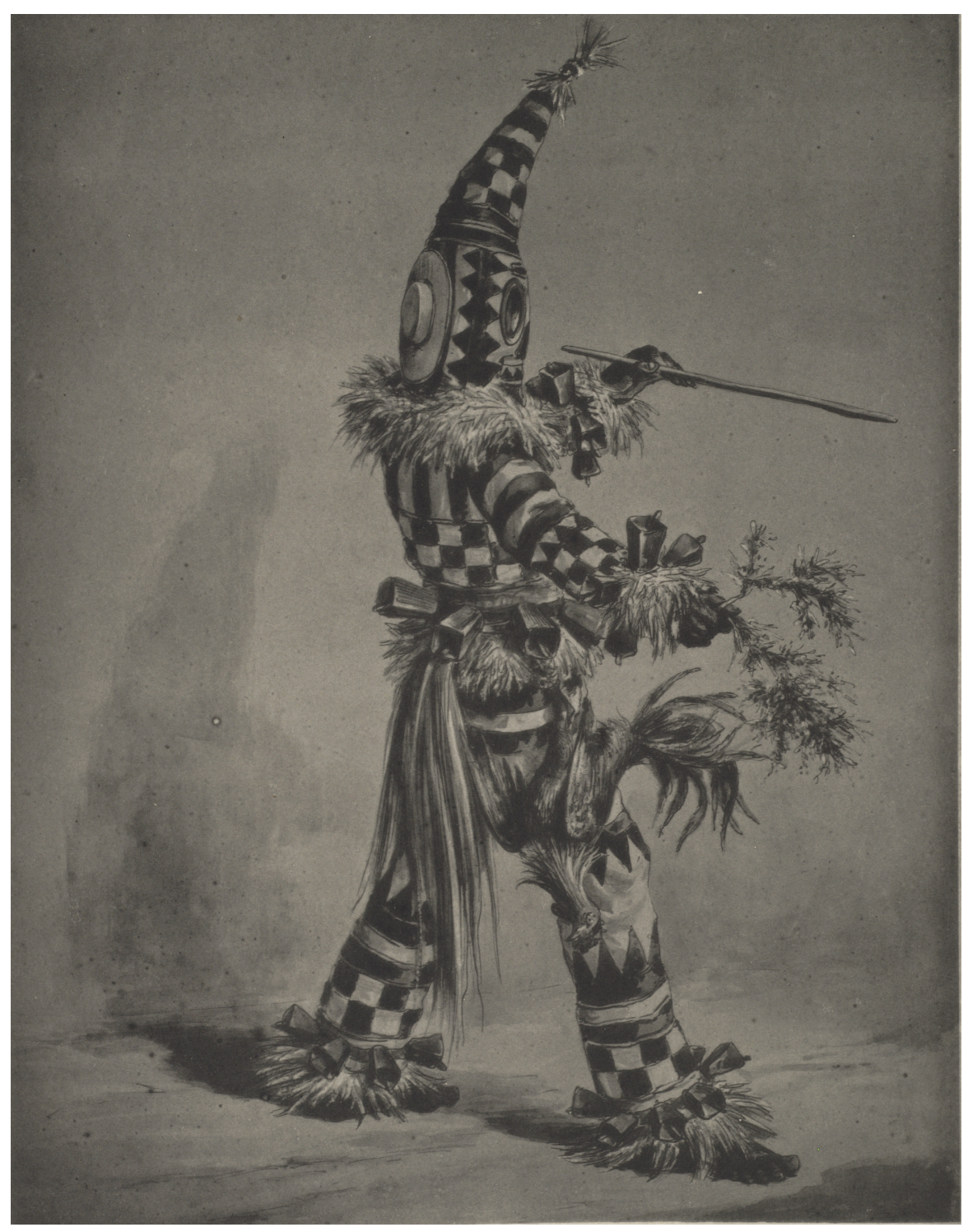


The Business Man, who has been observing the ritual with growing interest, jumps at the opportunity to incorporate it into his film. He chooses new costumes for the two actors. The Sailor puts on a tiger skin and necklaces. The Flapper wears a Hawaiian grass skirt and decorates her hair with flowers. The Business Man directs the actors to join the ritual. However, the participants block them angrily. Determined to carry out his plan, the filmmaker brandishes the camera tripod like a spear and tries to physically impose authority on the black men. The Iyamba and the Diablito confront him. Using magical powers, they conjure up fire under the intruder's nose. Blind with rage, the Business Man wields his tripod and smashes the altar. The worshipers are about to jump at him when a mysterious force paralyzes them. The Twins, Afro-Cuban deities, materialize as gigantic black puppets with bulging eyes and cylindrical bodies. Performing an ominous dance of heavy steps, they inch their way toward the terrified Business Man. They magically wrap a cord around his neck and strangle him with abrupt gesture. The skyscraper deflates. The sugar mill's siren wails somberly. The peasants, the Sailor, and the Flapper freeze, as the black worshipers raise their arms to the sky and the curtain descends slowly.

\section{The Racial Other's Dancing Body under the Colonialist Gaze: Cinema and Ballet}

The characters and situations in Milagro bear the mark of a long history of colonialist practices of observation, appropriation, and representation of non-European cultures. Initially manifested in Carpentier's oeuvre by way of the libretto's acerbic critique of cinema, the question of how Europeans and North Americans perceive and interact with the cultures of their colonies, former colonies or neo-colonies would become a motif of his work. In later years, the novels Los pasos perdidos (1953), El siglo de las luces (1962), and La consagración de la primavera (1978), in which European and North American travelers negotiate their immersion in Latin American environments, would attend to that concern. Carpentier's own hybrid identity fueled his curiosity about intercultural encounter and translation. Born to a French father and a Russian mother but raised in Cuba, he cultivated equally fervent interests in Europe and the Caribbean, and shifted fluidly between insider and outsider positions in reference to both regions' cultures - often taking the role of interlocutor between them, as when he reported on the European avant-garde for Cuban readers or lectured about Cuban music for French audiences. ${ }^{51}$

Early in his youth, Carpentier developed an appreciation of the cultures of territories with a history of colonialism. From uncritical acceptance of the identification of Europe with civilization and of Latin America, Africa, and Asia with barbarity, primitivism, and underdevelopment, he moved to a position that countered such colonialist hierarchy with a defense of the rich cultures of the latter regions. An initial indication of this transition appeared in his 1923 review of René Maran's Batouala, a novel that garnished considerable attention for fictionalizing the crude conflict between an African tribe and European colonists. Commenting on the novel, a nineteen-year-old Carpentier reiterated the stereotypical classification of Africans 
as "savages." He attributed the disastrous events of the literary narrative as much to the European characters' exploitative greed as to the African characters' "rudimentary mentality" and "coarse morality." While restating these racist tropes, the review attested to Carpentier's nascent concern with the question of how, in scenarios of colonialism, groups in opposite positions of power articulated schematic representations of each other. As it is, Carpentier proposed that the novel's primary theme was the incapacity of the two sets of characters to mutually regard themselves outside their preconceptions. If, in the novel, for the Africans a European doctor is a witch, "for the colonizer, Batouala [the African protagonist] is a simple beast that must be treated as such." 52

The fact that, four years later, Carpentier chose to denounce the cultural classifications of coloniality in a ballet about cinema was revealing, on the one hand, of cinema's new dominant role in disseminating narratives of the exotic and barbaric, and, on the other hand, of the salient place of dance in those narratives. Building upon the public's fascination with racial otherness and moving image technology, and banking in on mass reproduction and international commercialization, cinema had quickly become the medium par excellence for reproducing the discourse of non-European primitivism. Films extended the possibilities for the Western public to fulfill its curiosity about other races and cultures. The new technology could easily record non-Western bodies performing culturally specific behavior in their local environment. Now, the spectacle of otherness could be constructed with a sense of immediacy never achieved before. Movies such as Gaumont's Customs and Manners in Senegal (1910), Pathé Frères's Madagascar: Manners and Customs of the Sakalava (1910), and the Tahitian, Japanese, Javanese, and Cambodian installments of Gaston Méliès's "Round the World Films" (1912-13), turned travelogues into a popular genre of the incipient industry. Many of these movies fictionalized non-European cultures and locations according to stereotypes of primitivism and savagery. Osa and Martin Johnson's Cannibals of the South Seas (1912), filmed in Malekula, and Méliès's Captured by Aborigines (1913), set in Australia, traded in characterizations of the natives as cannibals and rapists. ${ }^{53}$

In Milagro, the Business Man's attraction to the Abakuá ritual bespoke cinema's obsession with the non-Western dancing body. The camera's capacity to capture human movement, coupled with the potential of dance for representing cultural difference, resulted in a proliferation of exotic dancing bodies on the celluloid. In the United States, one of the earliest applications of the new technology had been the filming of Plains Indians' ceremonial dances, as illustrated by Thomas Edison's Buffalo Dance (1894) and Circle Dance (1898). Fatimah Tobing Rony contends that films commonly portrayed the racial other as a subject that gestured and danced - communicating through physical actions rather than language. In these depictions, kinetic exoticism and verbal inarticulateness worked together to signify the supposedly lower evolutionary stage of Africans, Polynesians, Native Americans, and other colonial subalterns. Reinforcing the construction of a primitive physicality, the Non-Western subject was often caught in camera minimally dressed and executing actions like crouching and jumping, which situated him as evolutionarily close to apes. Darwinist theories that deemed posture and movement markers of evolution were appropriated in the representation of race, as it was evident 
in chronophotographic films by Félix-Louis Regnault from the 1890s that compared the walking and running of West Africans and Europeans. An advertisement for Cannibals of the South Seas made these associations apparent through the montage of the film's title, with its reference to cannibalism, and images of black men that included, in the background, a dancer holding a spear and striking a primitivist posture (Fig. 3). Even when the camera recorded authentic performances of dances and rituals, as was the case with Edison's movies and might have been with the hypothetic filming of an Abakuá ceremony in rural Cuba, the final product often generated a cultural gulf between the performers and their Western audiences. Decontextualized and unexplained, the performances appeared as aberrant behavior at odds with Western notions of civilization. ${ }^{54}$

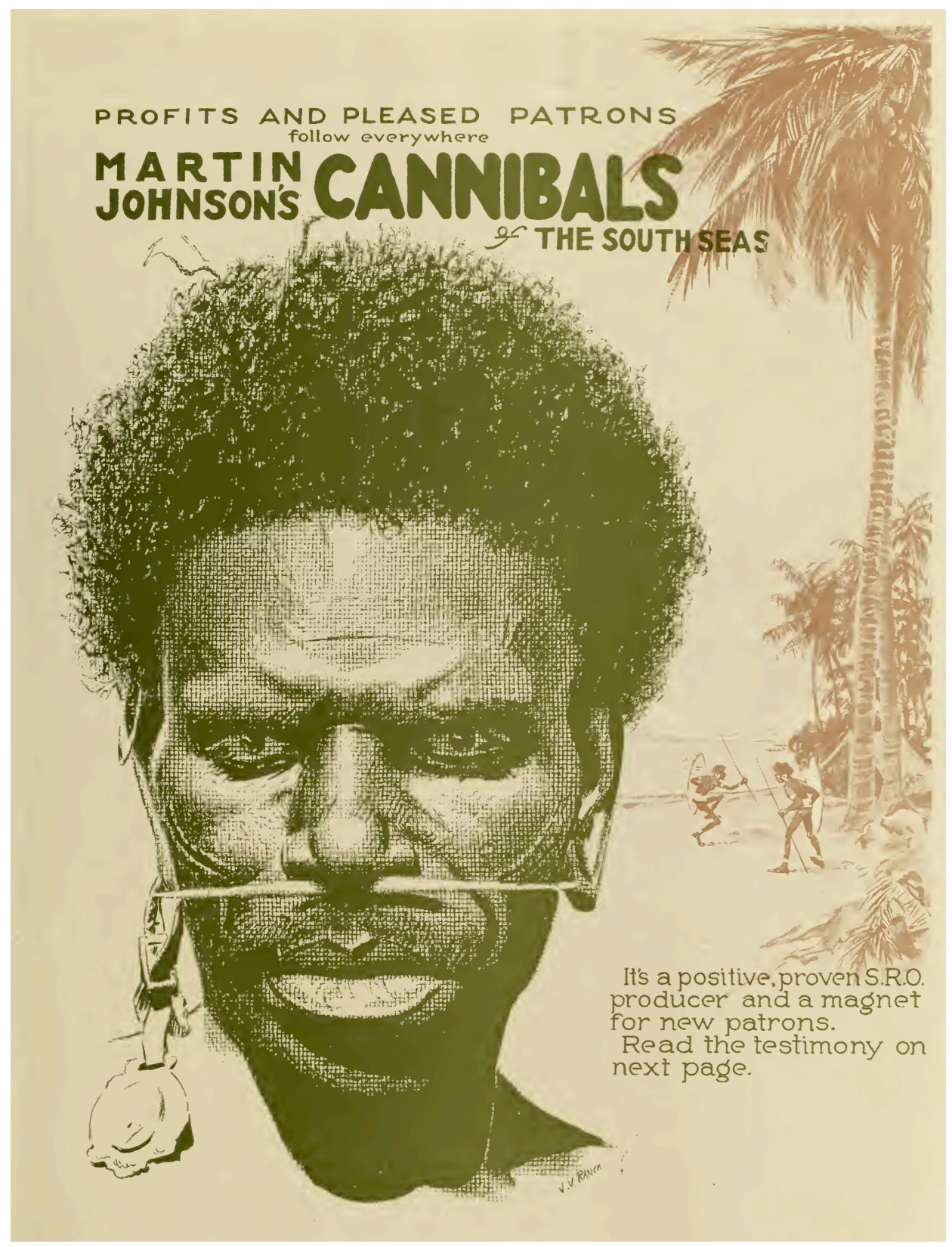


By the time Carpentier worked on Milagro, the colonialist discourse of European and North American cinema had become an object of condemnation in Latin American circles. In Mexico, a country that the librettist visited in 1926 right before writing the libretto, the denunciation of Hollywood's stereotypes of the region had reached diplomatic proportions. The administrations of Venustiano Carranza (1917-1920) and Plutarco Elías Calles (1924-1928) demanded that Hollywood studios put an end to their offensive depictions of Mexicans. ${ }^{55}$ Coinciding with Carpentier's stay in that nation, poet Gabriela Mistral intervened in the debate. Mistral, writing from Europe, reported that the cinemas of Paris and Brussels regularly projected US films that caricaturized Mexicans as "tribal" and "animalistic" people: physically weak and ugly, and inclined to violence, laziness, cowardice, alcoholism, and lechery. Grasping cinema's efficacy in shaping public opinion, she argued that such movies were poisonous propaganda that distorted the world's view of Mexicans and, by extension, other Latin Americans. ${ }^{56}$ Between June and July, her article appeared in El Universal (Mexico), El Mercurio (Chile), and Repertorio Americano (Costa Rica). Its broad diffusion spoke to the resonance that the issue had beyond Mexican borders. It is plausible that Carpentier's trip to Mexico informed his choice of topic for the ballet libretto one year later. The writer, who moved within Mexican artistic circles and made the acquaintance of the likes of painter Diego Rivera, acknowledged the trip to have been artistically and politically stimulating. ${ }^{57}$ With Hollywood's stereotypes of Mexicans occupying the attention of the intelligentsia, press, and government, Carpentier must have grasped, as Mistral, the relevance of the debate for all Latin American countries.

Milagro, then, should be contextualized as Carpentier's contribution to this regional protest of colonialist cinema. As such, it was not an isolated instance of the writer's involvement in the debate, which went beyond the allegory in the ballet libretto. He conveyed his explicit disapproval of this form of cinema in an article from 1931 that lambasted a French documentary about Mexico for its negative stereotypes of the country. Its display of indigenous people naked portrayed a rudimentary Mexico. Expressing bitterness for the "negative power" of foreign films to misrepresent the region, Carpentier stressed how vital it was for Latin Americans to make their own documentaries: "If to make films about ourselves we rely on foreigners, we can be certain of always being betrayed and deformed." ${ }^{, 58}$ Aware that this problem was not confined to Latin America, that same year the writer published an article that condemned a film about Africa that he had watched in Paris. The documentary's depiction of groups living between the Niger River and Lake Tanganyika reiterated tropes of savagery: "[The producers] can't manage to rid their words of a vague ironic tone, when they tell us about [the Africans'] magical practices, their sense of mystery, their concept of divinity, their laws, their witchdoctors, diviners and healers. As if in this realm primitive men gave more proof of barbarity than the children of [Western] countries do in some of their most usual actions. ${ }^{, 59}$ Carpentier argued that the filmmakers, coming from nations that had fought one another barbarously only a few years earlier, during World War I, had no right of claim to cultural superiority. For Carpentier, as for other intellectuals of his generation, the war's atrocities put in doubt the alleged role of Europe as the 
world's beacon of civilization, thus prompting a negation of the dualist opposition of Western development and non-Western barbarity.

The ritual scene in Milagro cites the representational codes of this category of movies, taking advantage of the ways in which the Abakuá ceremonial, framed as an archetypical vignette of primitivism, can meet the clichés of colonialist cinema. The black participants corporealize the discourse of barbarity by performing Africanist dances and exposing their bodies half-naked. They suggest backwardness when they crouch in a circle around the fire, while the Diablito jumps vigorously over the flames. Extraordinary ceremonial objects - such as the rooster, magic sticks, a feathered drum, and the Diablito's otherworldly mask-further place the ritual in counterpoint with Western notions of civilization. Carpentier cites yet another convention of primivitist cinema: the racial antithesis between natives and white actors. In their attempt to perform with the ceremony as their backdrop and donning the cartoonish grass skirt and tiger skin, the Flapper and the Sailor create a blackface spectacle of racial difference.

The subversion of the codes of colonialist cinema makes Milagro a postcolonial satire. The libretto appropriates and turns around a key element of colonialist representation, caricature, to expose the unethical and false character of this type of cinema. If European and North American filmmakers commonly relied on caricature to portray other cultures, now Milagro subjects those filmmakers' practices to the same reductionism, distilling them into a schematic picture of unscrupulous behavior. The Business Man's actions, scripted and exaggerated, stand as commonplaces of exploitative filmmaking, while his ersatz, simplistic construction of Spanish and Tarzanesque scenes reveals itself as a platitude of commercialism. And, just as celluloid caricatures dehumanized Africans, Asians, Polynesians, and Latin Americans by making them alternatively risible and intimidating, the libretto strips the Business Man of his humanity, turning him into a freak that causes both laughter and fright. In appearance and demeanor, he comes across as simultaneously ridiculous and monstrous. (As indicated earlier, avant-garde ballet and Futurist Theater provided Carpentier with the necessary elements to construct this caricature; the physiognomy and behavior of The Business Man had its equivalent in the hyperbolic, grotesque music hall managers from Parade).

In another subversive twist, Carpentier attributes an empowering role to magic and religion. This point is central to the ballet, as implied by its title (The Miracle of Anaquillé). The libretto claims a link to medieval miracle plays in which divine intervention remedy misfortune and injustice when saints come to the aid of troubled believers - although in the libretto the assisting divinities are Afro-Cuban. As Rony contends, the depiction of ritual and magic in colonialist cinema served to reinforce the savage image of the natives. ${ }^{60}$ From the perspective of Western modernity, the invocations and divinations of Africans were nothing more than obscurantism. Accordingly, the Business Man sees in the Abakuá ceremony only a futile cult that suits his plans for a colorful film scene. But this contemptuous view of Afro-Cuban religion carries deadly consequences. The filmmaker's profanation of the ritual unleashes magical forces that seal his fate. In Unruh's interpretation, the triumphant intervention of the Twin deities amounts to a statement about the superior cultural value of authentic Afro-Cuban religion in 
relationship to the falsehood and sterility of colonialist cinema. ${ }^{61}$ But the significance of this gesture is also political. What in colonialist discourse denoted atavistic behavior ranking low in the scale of cultural evolution, in Milagro becomes a fantastic element that endows the subaltern subject with the power to affirm his culture and sovereignty. ${ }^{62}$ This aspect of the libretto prefigured the political, real maravilloso theme of Carpentier's novel El reino de este mundo (1949) - in which runaway slave Mackandal appears to have the power to change shape into an animal and use this supernatural gift to promote the slave rebellion of the Haitian Revolution.

Milagro's revisionism of colonialist discourse extends beyond the sphere of cinema. It also targets ballet's own relationship with exotica. Before becoming an iconic institution of the avant-garde, Les Ballets Russes had achieved much of its fame thanks to peculiar embodiments of orientalism. The troupe's Slavic dancers were in-and-of themselves exotic for Parisian audiences who saw in Russians a people from outside the cultural confines of Europe, hailing from the continent's borderland with Asia. Furthermore, the ensemble's early repertoire showcased lurid spectacles noted for their representations of the "Orient" such as Cléopâtre (1909), Schéhérazade (1910), Thamar (1912), and Le Dieu Bleu (1912). Archetypically, Schéhérazade's story, taken from The Arabians Nights, took place in a harem. Bakst's decadent décors and risqué costumes (Fig. 4), Fokine's fleshly choreography, and Nikolai RimskyKorsakov's voluptuous music reiterated orientalist commonplaces of sexual hedonism and bacchanalian excess. The ballet's attraction rested on erotic imagery whose performance was permissible only if marked as exotic behavior. In orientalist fashion, Les Ballet Russes's performance of sexual desire attributed a reprehensible morality not to the European spectators for whose pleasure it was intended, but to the fictional Asian bodies of the narrative. ${ }^{63}$ An article from 1929 sheds light on Carpentier's disapproving outlook on such racialization of nonEuropean subjects. Reacting to these brand of ballet, Carpentier eloquently stated that the time was past for productions in which the "décors and dancers swam in a golden sauce of orientalism." He rejected a formula marked by "an invasion of silver turbans and indigo negroes, seraglios and temples, Samarkand envoys and Persian pointed sleepers, unrestrained exoticism and all the colors of the palette." He welcomed, as an alternative, Les Ballets Russes's embrace of Futurism, Cubism and other avant-garde trends. ${ }^{64}$

[Article continues in the next page] 


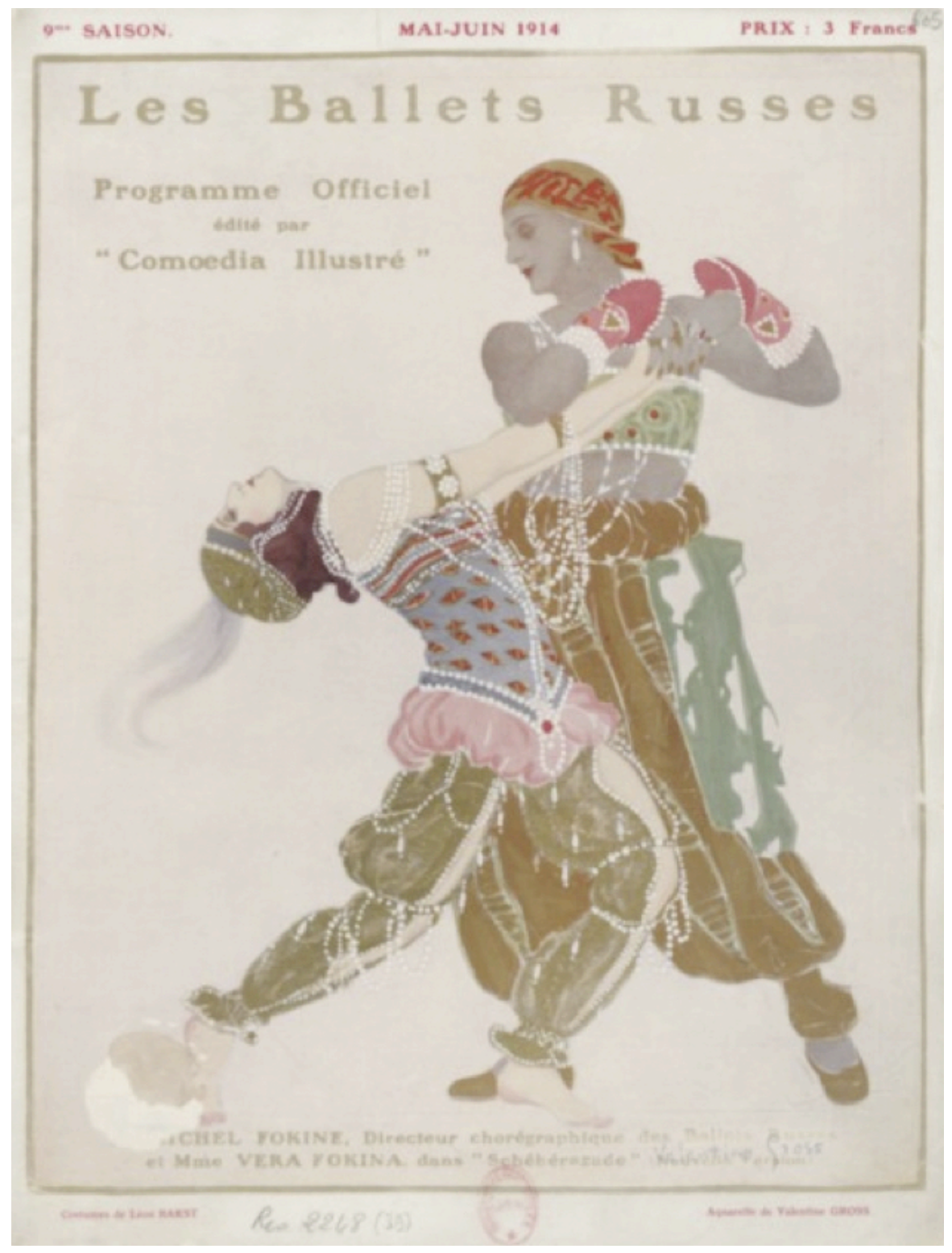

Just as Les Ballets Russes's output had transitioned from exotica to avant-gardism, Carpentier's own ballet projects quickly evolved from the postcard style of La rebambaramba to the astringent aesthetic of Milagro. Predating Milagro by one year, La rebambaramba features characters, situations, staging indications, and choreographic scenarios that fall under the picturesque style of Cuban costumbrismo. Through the magnification of local color, that libretto parallels the exotic character of orientalist ballet. It seduces with its vibrant views of Havana's colonial architecture, flamboyant recreation of an Afro-Cuban carnival, and sexually alluring mixed-race female protagonist. It must be noted, however, that under its glossy postcard surface La rebambaramba embeds a critique of the ideologies of patriarchy, racism, and colonialism of Spanish-ruled nineteenth-century Cuba. ${ }^{65}$ With Milagro, Carpentier proposed an interpretation of 
ballet that, while maintaining a political orientation, jettisoned facile exoticism and embraced an experimental aesthetic.

A declaration by Roldán illuminates the discarding of exoticism as more than an adjustment of the librettist and composer to the evolving stylistic paradigms of ballet. Their decision evinced a political response to another manifestation of the problematic link between coloniality and exotica: the classification of non-Western artists as purveyors of the exotic. Roldán struggled with the fact that in Europe his music was primarily appreciated for its colorful quality. He complained, "The music [from the Americas] up to now has been accepted in Europe mainly upon the basis of its outlandish flavor [...] with the accommodating smile with which grown people face a child's mischief, without giving it any real importance." In view of this, the musician clarified that a distinctive feature of his symphonic works, the integration of AfroCuban instruments, had a purpose more ambitious than producing a colorful sound. In his opinion, using those instruments to obtain "an easy local color" was not "artistically serious." $\mathrm{He}$ defended incorporating them in the orchestra, instead, for their richness of sonority and rhythmic precision, which highlights an experimental ethos in line with the modernist expansion of form and technique, as well as with the avant-gardist embrace of popular culture. Roldán asked that his music be judged "not on account of its exotic qualities," but by the same standards of compositional originality applied to European artists. ${ }^{66}$ Seen in this light, Milagro was a defiant gesture to any international expectations that Latin American artists limited themselves to producing colorful vignettes of their milieu. The librettist and composer's appropriation of the artistic tools of the avant-garde proved that Latin Americans could operate on the same cuttingedge terms as Europeans, rather than confine themselves to reproducing the conventional images that the metropolis associated with their region.

What is more, Milagro avails itself of the artistic devices of the avant-garde to launch its attack on the production of exotica. Taking an antipodal stance against realism and naturalism, avant-garde art generated non-realist forms of representing the world, such as Cubism, that brought attention to the inner workings and artifice of all artistic representation. For audiences, this entailed taking critical distance from the artwork as an image of life and, thus, interrogating the methods and intention of artistic representation. Unruh demonstrates that such capacity of avant-garde art for examining the representational process proved to be extremely attractive for those Latin American artists invested, for reasons ranging from the purely aesthetic to the overtly political, in producing a critical discourse of the aesthetic and ideological establishment. ${ }^{67}$ Operating in this manner, Milagro seeks to expose the fabricated character of the exotic representations of the racial other in colonialist cultural production. At first glance, the picturesque zapateo of the farmers and spectacular dances of the Abakuá might have seemed choreographic equivalents of orientalist ballet and colonialist cinema for a hypothetical spectator. Yet, Milagro's avant-garde aesthetic disrupts this view by pointing to the performativity of exotica. The projected décors situates the Cuban dances in a strange environment of Expressionist, Futurist, and Surrealist fixtures that destabilizes any illusion of realism. The set, with its flattened sugarcane field, disproportionate sugar mill, and nonsensical skyscraper, would 
have made the spectator aware of the incongruity between things and their artistic images, of the disparity between reality and its theatrical rendition. Placed in this context of theatrical artifice, the exoticism of dance and dancers would have appeared, too, as stylized performance, as yet another manipulation of reality through art. This was precisely the premise behind avant-garde ballet's approach to folkloric material, as explained by Lynn Garafola. Those works from the post-orientalist phase of Les Ballets Russes such as Chout (1921) and Le Renard (1922) that incorporated folklore (specifically, Russian folklore) placed emphasis on situating the ethnic material not as an actual representation of reality but as a product of a primitivist imagination to be observed through ironic distancing. ${ }^{68}$

The presentation of the Abakuá ritual within a metatheatrical framework permits Milagro to address in an even more transparent fashion the questions of how exotica is constructed, what relationship it holds to reality, and how colonialist cultural production represents the racial other. ${ }^{69}$ Through the adoption of this favorite resource of avant-garde performance (another nod to Parade, which also deployed metatheatre), Carpentier shows his adeptness at promoting critical spectatorship. The presence of the filmmaker's camera makes the Abakuá ceremony appear as theater within the theater or, more exactly, a potential movie scene within a ballet. In a classic alienation effect, á la Bertolt Brecht, the libretto generates two perspectives of the ritual and presses the audience into contemplating the difference between both: the ritual itself, as hypothetically performed in an authentic setting, and its (mis)representation through the lens of the camera. Such metatheatrical staging prompts spectators to imagine the transformation of the religious event into screen entertainment, and to consider the manipulation of the black dancers as an exotic human backdrop for ridiculous North American actors in a grass skirt and a tiger skin. Milagro forcefully denaturalizes the spectacle of exoticism in the film scene envisioned by the Business Man.

\section{Staging an Afro-Cuban Ritual: The Politics of Ethnography}

As much as avant-garde art postulated non-realist representation, in Milagro the intended contrast between an Abakuá ceremony and what would have been its Tarzanesque rendition rested on a realist staging of the ritual. It was by attempting a truthful recreation of the ceremony that Carpentier and Roldán could set themselves apart from filmmakers and choreographers who caricaturized non-European dance expressions. Accordingly, an extensive two-year period of dedicated research anteceded their work on the ballet. Starting in 1925, and following in the footsteps of Cuban anthropologist Fernando Ortiz, the librettist and composer studied black music and dance through direct observation. ${ }^{70}$ Carpentier's accounts of this research are fragmentary but contain enough details to align it with the emerging practice of ethnographic fieldwork, which Ortiz had pioneered in Cuba almost at the same time that European cultural anthropologists such as Bronislaw Malinowski and Marcel Mauss established participant observation as the core methodology of their discipline. ${ }^{71}$ Later in his life, Carpentier frequently reminisced of having attended "countless" Afro-Cuban dance and music events during those 
years, including rituals in the rural periphery of Havana and ceremonies that unfolded overnight. In these fieldwork activities, he was accompanied by Ortiz or Roldán (the musician took copious notes with the purpose of capturing motifs for his scores and developing an accurate system for transcribing the ways of beating, shaking, and scraping the various Afro-Cuban percussion instruments). ${ }^{72}$ As part of his research, Carpentier also worked with informants. He referred to having visited at least two Abakuá priests in their homes: one in the town of Regla, across the bay from Havana, and another one in a remote mountainous spot in the Santiago de Cuba region. $^{73}$

Casting Carpentier in the role of anthropologist might appear far-fetched. However, as Anke Birkenmaier and Emily Maguire have established, ethnography occupied a pivotal place in the writer's early production. ${ }^{74}$ Ultimately, Carpentier led a monumental career in journalism, literature, and criticism next to which his ethnographic endeavors stood as short-lived, apparently negligible efforts of youth. From a contemporary perspective, they appear to be a dilettante's work: undertaken without rigorous training, lacking precise methods, and oriented toward artistic rather than scientific production. But Carpentier was active in this field during a period, from the mid 1920s to the mid 1930s, when conducting ethnographic research did not necessarily presuppose having acquired the formal instruction that later came to be associated with the academic discipline of cultural anthropology. James Clifford rightly observes that at the time cultural anthropology had yet to achieve the status of a social science with distinct research methods. ${ }^{75}$ The training and methodologies of contemporary Cuban ethnographers corresponded with this. Ortiz, whose professional training had been as a lawyer, was a self-taught ethnographer. So was Lydia Cabrera, an artist by training who during those years overlapped with Carpentier at Afro-Cuban rituals and more than two decades later made fundamental contributions to the documentation of Afro-Cuban religion with her books El Monte (1954) and La sociedad secreta Abakuá (1958). ${ }^{76}$ In this regard, what looks like amateurism in Carpentier's anthropological work was, to an important extent, a reflection of historical limitations of the discipline, to which, as Maguire indicates, he and other Cuban ethnographers responded with necessarily experimental approaches. ${ }^{77}$

Carpentier's experimentation was palpable in the varied outcomes of his anthropological research. On the one hand, he wrote strictly ethnographic and musicological texts about aspects of Afro-Cuban culture and, particularly, the Abakuá. The articles in this category-"Lettre des Antilles" (1929), "La musique cubaine" (1929), "Cuban Magic" (1930), and "Images et Prières Nègres" (1933) - appeared in international periodicals that customarily featured ethnography alongside fiction, journalism, and criticism. ${ }^{78}$ On the other hand, his anthropological work also took the form of literary texts that approached the black themes typical of afrocubanismo through the lens of avant-garde aesthetics. The best known among these works is the novel Écue-Yamba$O ́$ (1933), which, as Birkenmaier argues, followed an ethnographic model of writing visible in the strong impetus to document Afro-Cuban culture through both descriptions and photographs. ${ }^{79}$ Similarly, Thomas Anderson details that knowledge acquired in fieldwork found expression in a handful of poems that Carpentier authored early in his career, including "Liturgia" and "Juego 
santo," both from 1927, which evoked the images and sounds of Abakuá celebrations. ${ }^{80}$ As part of this group of anthropologically inspired literary products, Milagro holds certain cues for assessing the level of exhaustiveness and even pioneer character of Carpentier's ethnographic studies, while also contributing a rare glimpse into the fraught relationship between the anthropologist and the subjects he observed in fieldwork. An examination of the ballet from these perspectives clarifies certain aspects of the anthropological work of Carpentier and, by extension, the other ethnographers of afrocubanismo.

The issue of achieving accuracy in the choreographic recreation of the Abakuá ritual is key to appraising the significance of Milagro, concerned as this project was with critiquing filmic and balletic distortions of non-European cultures. Later in life, Carpentier famously disavowed the representations of black traditions in his texts from the 1920s and early 1930s. He acknowledged that his ethnographic observations had been incomplete and that his understanding of certain Afro-Cuban cultural expressions was often erroneous. He explained that, not just for him but also for Ortiz and other ethnographers, researching the field of AfroCuban music, dance, and religion meant charting unexplored terrain, trying to understand traditions on which no scientific work had been previously done. Offering an example of the limitations of that work, Carpentier conceded that the music of Roldán was an inaccurate ethnographic record. In his scores, "the elements of that vast sonority of the Afro-Cuban realm are all mixed together" without distinction between a Yoruba hymn and an Abakuá ceremonial dance.$^{81}$ Carpentier also recognized the imperfectness of his own portrayal of Afro-Cuban traditions in Écue-Yamba-Ó: "everything that was deep, truthful and universal about the world that I tried to depict in the novel had remained outside the scope of my observation." 82

Compounded with the disciplinary limitations of early twentieth-century ethnography, this negative self-assessment reinforces the disqualifying perceptions of Carpentier's work as inept or of limited value. Yet, Milagro attests to the librettist's desire for exhaustiveness in documenting the Abakuá ritual of initiation. Even if in retrospect he denied the validity of his research, Carpentier asserted that the descriptions of Abakuá rituals in Milagro and Écue-Yamba$O$ were, in fact, precise representations of ceremonies he had observed. His self-acknowledged failure to fully understand the cosmology and culture that those rituals encapsulated did not preclude him from accurately recording the events' structure, participants, dances, liturgical objects, and other formal elements. In the preface accompanying the publication of the ballet libretto in 1937, he affirmed that Milagro had incorporated, "without any modifications, the choreographic ritual of [Abakuá] initiation ceremonies." He ratified this idea in the preface to the 1977 reprint of Écue-Yamba-Ó, in which he stood by the description of the Abakuá ceremony in the novel: "While not aspiring to be scientific, [it] reflects reality quite accurately." portrayal of the ritual in the libretto closely corresponds with Cabrera's detailed documentation of the Abakuá initiation rite. ${ }^{84}$ Carpentier did not record the totality of the ceremony, which extends for almost a full day and, for the most part, is open only to members of Abakuá groups. Instead, the ballet depicts the one section of the ritual that an outsider like Carpentier could have observed: the dances leading to the communion meal, which are performed in public. In essence, 
the scene in Milagro is similar to the performance of those dances as described in Cabrera's study, although Carpentier presents them in a schematic manner that obeys to a libretto's demand for synthesis. Keeping this in mind, the discrepancies between the two accounts are minor and could be understood as a result of the distinct aim of each text and the different scope of their supporting fieldwork - Cabrera's text is scholarly in nature and she authored it after more than two decades studying the ritual. ${ }^{85}$

In contrast to the textual accounts of the ritual in Carpentier's ethnographic articles and first novel, the ballet libretto proposes an experiment in staging the ceremony. Even though literary documentation could prove more permanent than a transient work for the stage, performance held the promise of capturing the ritual holistically by integrating dance, gesture, music, and costumes. For 1927, this was a revolutionary proposition that augured the researchto-performance ethnography of African diaspora traditions established by Zora Neale Hurston with The Great Day (1932) and Katherine Dunham with $L^{\prime}{ }^{\prime} g^{\prime} Y a$ (1938)-respective stagings of the Bahamian and Martinican dances that these anthropologists assiduously studied. ${ }^{86}$ Like Hurston and Dunham, who sought to cast their works with Caribbean dancers, Carpentier aimed to integrate native performers in the production of the ballet. ${ }^{87}$ He envisioned a staging not with professional performers, but actual "dancers from the people, knowledgeable of the folkloric rituals [and] capable of dancing what they knew through ancestral tradition." 88 Admittedly, this proposition conformed to practical considerations about producing the ballet in a country where there were no professional dance ensembles. Engaging black performers would have been opportune, too, to compensate for Carpentier's lack of mastery of the liturgical dances — which he had observed but not physically learned. However, regardless of its practical nature, such solution strategically advanced the ballet's stance against the colonialist representation of nonWestern cultures. The librettist must have understood how employing a cast of knowledgeable Afro-Cuban dancers could bring into relief the contrast between a living black tradition and the portrayal of this type of event in colonialist cultural production.

In her study of Hurston's The Great Day, Anthea Kraut takes stock of some of the challenges in research-to-performance ethnography. To be dealt with is the problem of authenticity in representation. Hurston's staging of the Bahamian Fire Dance in The Great Day consisted of an ethnographically informed adaptation of the original, which, by force, had to be modified to satisfy the demands of the theatrical medium. The transposition of a non-theatrical performance tradition for the stage requires taking the material out of its original context and extricating it from its social function. In the end, the dances and rituals studied in this manner enter the theater under artistic form, conforming to spatiotemporal conventions and modes of emplotment dictated by a theatrical logic. For an anthropologist in Hurston's situation, who had to assume responsibilities typical of a choreographer, the line between ethnographic documentation and artistic invention got blurred. As far as choreographic credits were a concern, the fact that her staging involved native dancers raised a question about their input in the production, pointing to issues of authorship and ownership. Hurston, who sought to remain as close to the ethnic material as possible, defended the genuineness of the staging. But, according 
to Kraut, her proclamation of authenticity, no matter how bona fide, had a commercialist connotation in that it constituted a strategy for marketing the show. In the end, independently of the production's degree of faithfulness, Hurston possessed limited ability to shape the work's reception: audiences interpreted The Great Day in terms of the exoticism and primitivism attributed to black dancing bodies. ${ }^{89}$ Since Carpentier and Roldán did not stage Milagro, it is difficult to predict how similar issues would have played out in rehearsals and performances. The libretto and stated production plan, while containing some clues, prompt more questions than answers. Conceptually, however, Milagro could offer apt solutions to issues of reception and authenticity. As argued already, the ballet created a model for critical spectatorship of the Abakuá ritual that negated the consumption of this ethnographic material as exotica. At the same time, by framing the ritual within an avant-garde environment that raised awareness of the constructedness of artistic representation, the ballet could circumvent debates about ethnographic authenticity. In fact, it opened the door to discussing the performativity of authenticity in performance-to-research anthropology. Going beyond these points, one may question how the collaboration between the producers and the cast of Afro-Cuban dancers would have unfolded, and, considering Carpentier and Roldán's distinction from the dancers in terms of racial identity and social status, what the politics of their relationship would have been. Without enough information to address these queries in a hypothetical context of rehearsals and performances, one could, instead, consider them in relationship to the librettist and composer's fieldwork.

Paradoxically, Carpentier's quest for accurate information about the Abakuá ritual could hardly take place outside the same matrix of colonialist ideology that Milagro condemned. In anthropology, the nexus between the observer and the observed had been traditionally characterized by lopsided power dynamics between educated white scientists from the imperial metropolis and non-white natives of the colonies assumed to be rudimentary. In the context of afrocubanismo, this asymmetric contact manifested in a divide between white intellectuals representative of the Cuban cultural elite such as Carpentier, Ortiz, and Cabrera, and the marginalized working class Afro-Cubans that they turned into a subject of study. The issue of racial relations lay at the heart of afrocubanismo. Through their research and artistic production, members of this movement advocated for rethinking the Cuban nation as a multiracial space inclusive of whites and blacks, and with a hybrid culture rooted both in Europe and in Africa. However, although clearly questioning racial relations at the scale of nation, these ethnographers and artists' own personal interactions with Afro-Cubans remained unexamined or, at best, elusively documented. The lack of commentary on this matter can be understood as another consequence of the theoretical stage of anthropology in the 1920s and 30s, when the practice of reflexivity had not yet crystallized into a mechanism for acknowledging and redressing the politically skewed interactions that take place in fieldwork. Maguire rightly observes that the details of participant observation and contact with informants are rare if not inexistent even in Ortiz's texts, in spite of his status as the most sophisticated of the island's ethnographers at the time. ${ }^{90}$ Similarly, the specifics of Carpentier and Roldán's fieldwork interactions are, for the most part, lost to the historical record. In "Images et Prières Nègres," Carpentier hints at the 
complexity of his racially mediated work with informants, but he takes no more than one sentence to address the thorny issue; he indicates that Abakuá priests in the vicinity of Havana "showed themselves distrustful of whites" interested in studying their religion. ${ }^{91}$

The sparseness of information about interracial tensions in fieldwork makes the more significant an anecdote from the research process for Milagro that Carpentier related more than a decade later, in 1939. According to the writer, he and Roldán had shown up to an Abakua initiation ritual with the purpose of gathering material for the ballet. The composer took copious notes and transcribed musical motifs directly onto music sheets until the performance came to an unexpected halt.

All of a sudden, we noticed that an atmosphere of discomfort and hostility took hold of the festivity. An extraordinary diablito in red and blue hid in the cuarto fambá [the altar room]. The drums became silent. The worshipers gave us chilling glances.

"What are you writing down?" asked the iyamba, who had seen Roldán at work.

"Nothing... The music," the composer replied.

"And what for are you writing the music down?"

"For composing some danzones," affirmed Amadeo to avoid getting into a more complex explanation [of plans for a ballet].

But the answer did not satisfy the obón [iyamba].

"If you want to avoid a tragedy, put away the notebook and pencil. No one comes here to compose danzones."

In spite of the suggestion that we went somewhere else, we stayed at the festivity trying to record the rhythms and words in our brains. ${ }^{92}$

The story sheds light on how ethical problems and disagreements with subjects could mark the fieldwork of ethnographers who studied Afro-Cuban ceremonials. The incident captured in the anecdote was not an isolated example. Elsewhere Carpentier noted that frictions about data collection emerged repeatedly: "As we have experienced on many occasions, [the Abakuá] oppose the notation or phonographic recording of their ritual music, which they consider a profanation of their secrets. "93 While in his anecdote Carpentier made no reference to the racial and social rift that informed the conflict, it is implicit that such separation was at the heart of it. In more than one way, he and Roldán stood out as strangers among what was, in all likelihood, an assembly of working-class Afro-Cubans. Racial distinctions were prominent. Of French and Russian ancestry, Carpentier was white. And Roldán, the son of a Spaniard and a mixed-race Cuban woman, had fair skin that allowed him to pass as white. Their status as intellectuals with an education strongly rooted in European culture further distanced them from a popular community that practiced an African-rooted religion. Home-schooled by his foreign parents, Carpentier spoke French and, as detailed earlier, was well versed in European literature, music, and art. Meanwhile, Roldán had enjoyed extensive training as a violinist in the Madrid Conservatory. Even in terms of nationality the writer and the composer contrasted with the Abakuá group. Carpentier had been born in Lausanne and Roldán in Madrid. Judging from the testimony of literary critic Juan Marinello, some of Carpentier's contemporaries saw him more 
as Franco-Cuban than as integrally Cuban. ${ }^{94}$ Roldán's national identity could have been perceived as equally undefined. Having grown up in Spain, he had lived in Cuba for only eight years by the time the episode took place. ${ }^{95}$

It is remarkable how much Carpentier and Roldán's field experience with the Abakuá resembled the confrontation of the US filmmaker and the Afro-Cuban worshippers in Milagro. Analogously to the characters of the ballet, the participants in the anecdote were set apart by the marked differences of racial identity and social status pointed above. Both in real life and in the libretto those differences informed relations of power and resistance between the involved actors. Carpentier and Roldán, as the filmmaker, recorded the Abakuá ritual without consent and, even after a warning from the priest, insisted on doing so. Also as the filmmaker, they sought to appropriate elements of the ritual for an artistic enterprise of their own, a ballet that, not unlike the North American's movie, put forward a representation of Afro-Cubans by outsiders. Meanwhile, the iyamba, as the priest in the ballet, resisted the intruders' observation and threatened them with violent retaliation. The close parallel between the fieldwork incident and the scene in the libretto strongly supports the notion that real-life experience inspired that passage of Milagro, with complicates an interpretation of the ballet as a critique of coloniality. How is it possible to reconcile Milagro's denunciation of the colonialist discourse of racial otherness with its own reproduction of colonialist dynamics in fieldwork? Given the resemblance between the actions of the fictional filmmaker and those of the authors of the ballet, it seems evident that Carpentier wrote the libretto with an understanding of the similarities between colonialist cinema and anthropology. Not just an archetype of a certain class of filmmaker, the Business Man stood, too, as an avatar of Carpentier and Roldán in their roles as ethnographers. By assigning such dual identity to a character constructed as an anti-hero, the librettist hinted at the ethically problematic overlap between the behavior of the filmmaker and the practices of ethnographers.

Similarly to the travelogue, safari, and explorer genres in cinema, anthropology had developed in dialogue with imperialist history. Victorian explorers, missionaries, and government officials such as George Grey, Thomas Williams, and Francis Galton, who acted as propagators of British imperialism, produced accounts of African, Australian, and Polynesian cultures that gave fodder to the theories of racial determinism and social evolutionism that came to dominate anthropological theory in the nineteenth century. ${ }^{96}$ Born from the colonialist enterprise, those theories, in turn, lent themselves to legitimizing European colonial ruling as an expression of the alleged superiority of Europeans, or as part of a civilizationist project directed to the supposed advancement of those societies deemed barbaric and inferior. ${ }^{97}$ In disciplinary terms, the same logic normalized the ethnographer's position of superiority in relation to the groups he studied. Only a few years before the creation of Milagro had anthropology begun to abandon the evolutionist and eugenicist theories that posited the cultural and racial supremacy of Europeans. This shift had started at the turn of the century with Franz Boas's proposition that societies should be analyzed through the lens of their own history and culture, which implied the dislodging of Eurocentric perspectives from anthropological research. In a corollary of it, 
fieldwork emerged as the essential methodology of cultural anthropology. Through systematic participant observation, as Bronislaw Malinowksi demonstrated in Argonauts of the Western Pacific (1922), ethnographers could achieve a detailed understanding of other cultures and the natives' own points of view. The transformation in anthropological paradigms outlined here found expression in the study of black culture in Cuba, something patent in the reorientation of Ortiz' research over the initial decades of the new century. From having first examined black culture from a criminological standpoint that linked Afro-Cuban religion to illegal behavior in Los negros brujos (1906), Ortiz moved toward affirming the value of Afro-Cuban culture in his works on music from the $1920 \mathrm{~s}-30 \mathrm{~s}$, and overtly negating racism and the very concept of race a decade later in El engaño de las razas (1946).

The contradiction between Milagro's indictment of the Business Man and Carpentier and Roldán's own fieldwork practices could be understood against this background of shifting anthropological principles. Proceeding in tandem, the repudiation of Eurocentrism and the endorsement of fieldwork pointed to an eventual revolution in the politics of participant observation. To conduct fieldwork while negating Eurocentrism would mean, ultimately, renouncing colonialist ideology and, therefore, questioning the position of power of ethnographers relative to the subjects they observed. But such postcolonial conception of fieldwork, which would take decades to evolve, remained unformulated at the time that Carpentier and Roldán studied the Abakuá rituals, between 1925 and 1927. By then, the professionalization of participant observation had merely begun with Malinowski's publication of Argonauts in 1922 and Marcel Mauss's inception of the Institut d'Ethnologie in Paris in 1925. Milagro was typical of this transitional moment. It shared the Boasian opposition to the representation of non-Western cultures from a Eurocentric standpoint—expressed as primitivism and exoticism in cinema. ${ }^{98}$ At the same time, the ballet reflected the incomplete development of fieldwork procedures that constituted an alternative to colonialist ethnography. Seen in the context of Cuban anthropology, Milagro evinced, too, the signs of a transition. Expectedly, since Carpentier and Roldán entered ethnography under Ortiz's guide, the ballet was indicative of the shift from criminology to cultural anthropology in the study of Afro-Cuban traditions. In similar fashion, the librettist and composer's ethnographic methods were idiosyncratic of the 1920s in that their problematic limitations revealed how far Cuban anthropologists still were from establishing a radical critique of racism of the sort that Ortiz articulated in the 1940s.

Locating Carpentier and Roldán's ethnography in a context of critical changeover in anthropology does not seek to justify the questionable interactions described in their fieldwork anecdote. However, this contextualization illuminates the historical significance of a libretto that recognizes the problematic resemblance between the modus operandi of the Business Man and colonialist practices in ethnography. In itself, such an acknowledgment evidenced the shifting values in anthropology by suggesting the ethical invalidity of ethnographers' authoritarian treatment of subaltern groups. To this extent, then, Milagro embedded a provocative if veiled commentary on ethnography. Written with awareness of the politics of fieldwork, the libretto did not go as far as making them explicit for a general audience. Carpentier's anecdote, published 
thirteen years after the genesis of the ballet, illuminated those politics only in retrospect. Had the ballet been staged at the time of its conception, most spectators would have missed its allegory of ethnography, but not those figures of afrocubanismo who engaged in fieldwork. Researchers like Ortiz and Cabrera, and artists who frequented Afro-Cuban rituals in search of material for their nationalist artworks, would have grasped the parallel between their ethnographic activities and the Business Man's actions. In other words, Milagro invited a reflection on the ideological underpinnings of fieldwork among precisely those who should consider them critically. Inasmuch as the field of anthropology had not yet developed a theory of reflexivity and postcolonial critiques of its practices, it is notable that a novice ethnographer's ballet libretto hinted at the racial tensions and conflicting interests that characterized the contact with subjects. Milagro could be seen as a seminal point in Carpentier's trajectory toward articulating more explicit postcolonial assessments of anthropology — which manifested, eventually, in the already cited critiques of documentaries on Mexico and Africa, as well as in his later disavowal of his own ethnographic work.

As Carpentier and Roldán's proposition in avant-garde ballet, El milagro de anaquillé constituted a gesture to bring Cuban artistic production up to date with cutting-edge artistic trends that had recently flourished in Europe. On the surface, the librettist and composer's embrace of ballet and avant-gardism appeared to reiterate a Eurocentric logic by which Latin American artists and nations ought to follow aesthetic dictates and definitions of development from Old World metropolises. However, Milagro evidenced the much more complex and critical relationship of the region's artists to discourses of Eurocentrism and coloniality. For Carpentier and Roldán, adopting avant-garde vocabularies served a purpose larger than catching up with the latest artistic innovations from Europe. For them, the disruptive techniques of avant-garde art, so well suited for interrogating reality and the very same process of artistic signification, became a toolkit for producing a political piece that questioned Western representations of cultural and racial otherness. By showcasing these authors' adept manipulation of the elements of avantgarde ballet, theater, and music in function of an incisive critique of colonialist spectacles of primitivism and exotica, Milagro also opposed pre-established assumptions about the scope of Latin American artistic production. Carpentier and Roldán claimed for themselves the status of modernizers commonly reserved for artists from European cultural centers, while rejecting any colonialist expectations on Latin American artists to produce works that reinscribed the assumed exoticism of the region. Similarly, the ballet contested the geographically and racially preassigned classifications of civilization and barbarity in the colonialist discourse of European cultural domination.

Milagro reflected profound artistic and political transformations in Cuba and abroad at the time of its creation, sometimes in pioneer fashion. Not only did the piece spearhead the espousal of avant-gardism among the island's artists; it was also an early expression of the cultural production of afrocubanismo. At the same time, it channeled the peaking anti-imperialist sentiment and protest of US interventionism among the Cuban intelligentsia at the time. 
Furthermore, Milagro illustrated cinema's popularization and conversion into the preeminent medium for reproducing narratives of primitivism and exotica, while also standing as a manifest to the growing opposition of Latin American intellectuals to this phenomenon. Moreover, Carpentier and Roldán's project attested to ballet's creative resurgence, shift from exotica to avant-gardism, and international proliferation in the early twentieth century. Finally, Milagro remains a testament to historic reformations in the arena of cultural anthropology. As such, it embodied the contradictions that marked a period of change in that discipline. Carpentier and Roldán's fieldwork study of Afro-Cuban rituals corresponded with the ascendance of participant observation as a data-collection method, while their ballet prefigured the research-toperformance approach to ethnography. In exposing and mocking the Western construction of non-Western exoticism, their proposed staging of the Abakuá ceremony coincided with the Boasian turn in anthropology, which spurned the Eurocentric biases in the interpretation of cultures. But even as anthropologist were beginning to rebuff colonialist theories of social evolutionism and racial determinism, the creators of Milagro could not fully overcome ethicopolitical faults rooted in the supremacy of the ethnographer in colonialist anthropology. Positioned by their racial identity and social status in a hegemonic relation vis-à-vis Afro-Cubans subjects, Carpentier and Roldán banked in on this lopsided dynamic to gather material for the ballet. And, yet, the questionable character of this form of anthropological authority did not escape the author of the libretto. Self-criticism, expressed in the text's veiled parallel between an unscrupulous filmmaker and an ethnographer, did not redeem Carpentier and Roldán's research tactics, but, in keeping with the pioneer character of the ballet, opened the door to reflecting on the power disparities of fieldwork.

\section{Acknowledgments}

This study was supported through fellowships from the National Endowment for the Humanities and Harvard University's David Rockefeller Center for Latin American Studies. Grants from Smith College provided additional support for research trips to Havana. I thank these institutions for their funding. I also thank Graciela Pogolotti, Rafael Rodríguez Beltrán, Armando Raggi and Xonia Jiménez from the Fundación Alejo Carpentier for facilitating my access to the author's papers and other archival materials. I am grateful too for the valuable feedback received from this journal's anonymous reviewers and colleagues in the Boston Workshop for Historians of Latin America and the Caribbean, led by Kirsten Weld. Additionally, I am indebted to Lynn Garafola and Justin Crumbaugh for exchanges on topics related to this article.

\footnotetext{
${ }^{1}$ A. Carpentier, "Un ballet afrocubano," in Revista Cubana (Havana) vol. VIII, no. 22-24 (April-June 1937), 14554.

${ }^{2}$ See R. Moore, Nationalizing Blackness: Afrocubanismo and Artistic Revolution in Havana, 1920 -1940 (Pittsburgh: Univ. of Pittsburgh Press, 1997).

3 “Declaración del Grupo Minorista," in Social (Havana), June 1927, 7.

${ }^{4}$ A. Carpentier, "El recuerdo de Amadeo Roldán," in Carteles (Havana), June 4, 1939, reproduced in Obras completas vol. IX (Mexico City: Siglo XXI, 1986), 426.

${ }^{5}$ Carpentier is quoted in P. Tovar, "Ideas y sonidos de Alejo Carpentier: la danza de las palabras," in Alejo carpentier: América, la imagen de una conjunción (Barcelona: Anthropos, 2004, 55).
} 
${ }^{6}$ In attributing a postcolonial character to Milagro, this article connotes a critical relationship to coloniality not merely in terms of Cuba's political status as a former colony of Spain — or a neocolony of the United States at the time of the libretto's creation. Rather, the term "postcolonial" is used here to define opposition to what Aníbal Quijano calls "coloniality of power": a long-lasting global social order and hierarchical system of cultural and racial classification that, having transcended the politico-territorial domination of colonies and neocolonies under European colonialism and Western imperialism, continues to situate certain nations, cultures and races in relationships of subordination to Europe and the West. A. Quijano, "Coloniality and Modernity/Rationality," in Cultural Studies vol. 21, nos. 2-3 (2007), 168-71.

${ }^{7}$ Establishing a historical and aesthetic distinction between modernism and avant-gardism aids in clarifying the artistic nomenclature followed in this article. Given that modernism comprehends avant-gardism, a distinction could be debatable and the elements of any given ballet (i.e., choreography, music, libretto, sets and costumes) could be labeled individually as modernist or avant-gardist. In general, I consider avant-garde ballets those that espoused Cubism, Futurism, Surrealism, Constructivism and other radical artistic trends that flourished in Europe beginning around 1910 and extending into the 1930s. Almost all works of Les Ballets Suédois fall within this category, as do several of the works of Les Ballets Russes after World War I. Meanwhile, modernist ballet is a broader field that includes such cutting-edge pieces as well as other works that, in spite of being revolutionary for their time, were not as radical in their break with tradition. Most of the prewar Primitivist and Neo-Romantic repertoire of Les Ballets Russes exemplifies a modernist sensibility distinguishable from avant-garde radicalism. Even though distinctions between modernism and avant-gardism are specific to genre, for the sake of consistency here I follow a similar criterion (based on historical periodization and degree of aesthetic radicalism) to differentiate between modernist and avant-garde art, theater and music. As demonstrated here, Carpentier expressed interest in both modernist and avant-garde artistic production, but it was the latter that he found the most fascinating.

${ }^{8}$ In Janney's opinion, Milagro introduces a construction of archetypal characters that embody the collective, manifest in Carpentier's novels. F. Janney, Alejo Carpentier and His Early Works (London: Tamesis Books), 26-32; and V. Unruh, Latin American Vanguards: The Art of Contentious Encounters (Berkeley: Univ. of California Press, 1994), 64-66.

${ }^{9}$ V. Unruh, Latin American Vanguards: The Art of Contentious Encounters, 2-3, 8.

${ }^{10}$ Carpentier's poems "Liturgia," "Marisabel," and "Juego santo" were musicalized by García Caturla in 1928. That same year, Carpentier and the French composer Marius-François Gaillard created Yamba-O, a tragédie burlesque for voices and orchestra, followed in 1929 by Poèmes des Antilles, a cycle of nine songs for soprano and piano. A third collaboration with Gaillard resulted in La Passion noire (1931), an oratorio for vocal soloists, chorus and large orchestra with an Afro-Cuban percussion section. Additionally, Carpentier worked with Edgar Varèse in Canción de la niña enferma de fiebre (1930) for soprano and orchestra. Together with Robert Desnos, he devised the libretto for another piece by Varése: The One All Alone, an ambitious surrealist work for the stage that the composer did not complete. During this same period, Carpentier also wrote the libretto of the comic opera for puppets Manita en el suelo (1937), whose scoring Roldán did for the most part, but without finishing it, before his death. Carpentier's final musical project, with Milhaud, was Incantations (1939), for unaccompanied male voices. For an analysis of this body of work, see A. Birkenmaier, Alejo Carpentier y la Cultura del Surrealismo en América Latina (Madrid: Iberoamericana-Verveurt, 2006), 181-96; C. Rae, "In Havana and Paris: The musical activities of Alejo Carpentier," in Music \& Letters vol. 89, no. 3 (2008); and T. F. Anderson, Carnival and National Identity in the Poetry of Afrocubanismo (Gainesville: Univ. Press of Florida, 2011): 49-78.

${ }^{11}$ Vicky Unruh, Latin American Vanguards: The Art of Contentious Encounters, 3, 22-23.

${ }^{12}$ A. Birkenmaier, Alejo Carpentier y la Cultura del Surrealismo en América Latina; and E. Maguire, Racial Experiments in Cuban Literature and Ethnography (Gainesville: Univ. Press of Florida, 2011).

${ }^{13}$ For examples, see A. Carpentier, "La música rusa en París," in Chic (Havana) v. 12, no. 96 (August 1923), 30; "Las enseñanzas de Satie," in Chic vol. 13, no. 105 (May 1924), 34-35; "Cocteau y sus teorías sobre el teatro," in El Heraldo (Habana), October 7, 1924, 7; "El arte múltiple de Picasso," in Social vol. 10, no. 9 (September 1925), 29; and "Música nueva: Francis Poulenc," in Diario de la Marina (Havana), October 23, 1927, 44. 
${ }^{14}$ C. Rae, "In Havana and Paris: The musical activities of Alejo Carpentier," 378-82.

${ }^{15}$ C. Ripoll, "La Revista de Avance (1927-1930): vocero de vanguardismo y pórtico de revolución," in Revista Iberoamericana vol. 30, no. 58 (1964), 261-82.

${ }^{16}$ Roldán and García Caturla gained exposure to modernist music through their studies with Spanish conductor Pedro Sanjuán. See H. Orovio, Cuban music from A to Z (Durham: Duke Univ. Press, 2004), 90-91, 185.

${ }^{17}$ Other Cuban painters who gained familiarity with the new aesthetics were Wilfredo Lam (a protégé of Picasso), Amelia Peláez (who studied the work of Picasso, Henri Matisse, and Georges Braque), Carlos Enríquez (who referenced the work of Francisco Picabia), Eduardo Abela (an adept of Marc Chagall), and Marcelo Pogolotti (an affiliate of the Futurist group). See M.C, "Exposición Gattorno," in Revista de Avance vol. I, March 15, 1927, $15-$ 16; and J. A. Martínez, Cuban Art and National Identity: The Vanguardia Painters, 1927-1950 (Gainesville: Univ. Press of Florida, 1994), 5, 14.

${ }^{18}$ L. Garafola, "The Making of Ballet Modernism," in Dance Research Journal vol. 20, no. 2 (1988), 23-32.

${ }^{19}$ A. Carpentier, Recuento de moradas, section no. 4, Fundación Alejo Carpentier, http://www.fundacioncarpentier.cult.cu/carpentier/recuento-de-moradas, accessed July 19, 2015; J. A. González, "El ballet en Cuba hasta 1948," in Cuba en el ballet (Havana), vol. 4, no. 3 (September 1973), 45-47; and F. Rey, "Siglo y medio de danza en el Gran Teatro de La Habana," in Cuba en el ballet vol. 7, no. 2 (April-June 1988), 2-9.

${ }^{20}$ Carpentier writes about those magazines, but without indicating their names, in a letter from 1929 to his mother, Lina Valmont. A. Carpentier, Cartas a Toutouche (Havana: Letras Cubanas, 2010), 154-55.

${ }^{21}$ A. Carpentier, "La última labor de Igor Stravinsky," in La Discusión (Havana), July 15, 1923, 3.

${ }^{22}$ A. Carpentier, "Las enseñanzas de Satie"; "El ballet moderno," in Chic vol. 12, no. 97 (September 1923), 18-19; "Ravel y la música descriptiva," in Chic vol. 13, no. 102 (February 1924), 34-35; and "Grandeza y decadencia del cubismo," in Chic vol. 13, no. 108 (August 1924), 36-37.

${ }^{23}$ A. Carpentier, “Ordenado, disciplinado, trabajador y consciente,” in Amadeo Roldán: Testimonios, ed. M. A. Henríquez and J. Piñeiro Díaz (Havana: Letras Cubanas, 2001), 50.

${ }^{24}$ As Roberto González Echavarría argues, Carpentier was regarded more as a commentator on the arts than as an artists himself during the initial years of his career. R. González Echavarría, Alejo Carpentier: el peregrino en su patria (Madrid: Gredos, 2004), 76. Carpentier's nomination to the Nobel Award is reported in "Alejo Carpentier, propuesto para el Nobel de Literatura," in El País (Madrid), October 9, 1979.

${ }^{25}$ P. de Groote, Ballets Suédois (Ghent: Academia Press, 2002), 20-78.

${ }^{26}$ A. Carpentier, "El ballet moderno"; "Actividades artísticas en Europa," in El Heraldo, October 31, 1924, 7; and "Jean Cocteau y la estética del ambiente," in Social no. 7 (July 1925), 41, 49, 59, 81.

${ }^{27}$ A. Carpentier, "Las enseñanzas del murciélago," in El Heraldo, November 11, 1924, 7; and "Hacia un teatro sintético cubano," May 22, 1925, reproduced in the website of the Fundación Alejo Carpentier, http://www.fundacioncarpentier.cult.cu/carpentier/hacia-un-teatro-sint\%C3\%A9tico-cubano, accessed July 17, 2015.

${ }^{28}$ A. Carpentier, letter to A. García Caturla from March 15, 1927, in Obras completas vol. 1 (Mexico City: Siglo XXI, 1983), 281-82.

${ }^{29}$ When the information is available, I date Carpentier's librettos according to the year when he wrote them. Other studies have dated them according the year when the music was composed, published, or premiered, or when the librettos appeared in print. In his notes to the program for Ramiro Guerra's production of the ballet, Carpentier indicates that he penned La rebambaramba in 1926. In the same program, he states that El milagro de anaquillé dates from 1927. See Conjunto de Danza Moderna, Auto sacramental, Suite Yoruba, El milagro de anaquillé, Concerto grosso, La rebambaramba, souvenir program for performances on January 25, 1962, Teatro Nacional de Cuba, Havana.

${ }^{30}$ For the libretto of La rebambaramba and my analysis of it, see A. Carpentier, La rebambaramba, in Obras Completas vol. 1, 195-207; and L. Tomé, "Envisioning a Cuban Ballet: Afrocubanismo, Nationalism and Political Commentary in Alejo Carpentier and Amadeo Roldán's La rebambaramba," in Dance Research Journal of Korea vol. 71, no. 5 (2013), 157-81. 
${ }^{31}$ See A. Piñeiro, "Alejo Carpentier: todo en la danza le fue cercano," in Cuba en el ballet no. 94 (May-December 1999), 40-47.

${ }^{32}$ A. Carpentier, La hija del ogro, ballet libretto, file MFP3, no. 1-3, Fundación Alejo Carpentier.

${ }^{33}$ A. Carpentier, "Un ballet afrocubano."

${ }^{34}$ Frank Janney includes Azúcar and Mata-Cangrejo in his bibliography of Carpentier's works, but it remains unclear whether the author ever completed these librettos. F. Janney, Alejo Carpentier and His Early Works, 133.

${ }^{35}$ Letters exchanged between 1928 and 1931 confirm that Carpentier did not complete the libretto for El embó. When in 1931 the writer finally submitted a finished text to García Caturla, the project had metamorphosed into the comic opera for puppets Manita en el suelo. See García Caturla's letters from November 3, 1928, and April 29, 1931, and Carpentier's letters from July 6, 1931, and August 16, 1931 in A. Carpentier, Obras completas vol. 1, 288, 294-300.

${ }^{36}$ In later years, Carpentier would author three other ballet librettos. He wrote Romeo y Julieta and Casa de baile for composer Hilario González, who dates their collaboration to 1942. Both texts have been preserved, in addition to an untitled ballet libretto from 1960 allegorical of the history of Cuba since its colonization to the Revolution. See Casa de baile, folder 55; "Notas para ballet" [Romeo y Julieta], folder 194; and "Un ballet inédito, 1960," folder 41, in Fundación Alejo Carpentier. See also H. González, "Alejo Carpentier: precursor del 'movimiento' afrocubano," preface to A. Carpentier, Obras completas, vol. 1, 14-17; and L. Tomé, "Regreso al ballet: Un libreto de Alejo Carpentier," in Cuba en el ballet no. 125 (January-April 2013), 47-52.

${ }^{37}$ A. Carpentier, letter to A. García Caturla from March 15, 1927.

${ }^{38}$ L. Tomé, "Envisioning a Cuban Ballet: Afrocubanismo, Nationalism and Political Commentary in Alejo Carpentier and Amadeo Roldán's La rebambaramba (1928)".

${ }^{39}$ A. Carpentier, letter to A. García Caturla from March 15, 1927.

${ }^{40}$ Alberto Alonso produced La rebambaramba for the Havana television station CMQ-TV. The ballet aired on September 13, 1957. Ramiro Guerra staged Milagro with the National Theatre's Modern Dance Ensemble, also in Havana. It premiered on July 1, 1960. Guerra also choreographed La rebambaramba for that troupe, a production that was first seen on February 18, 1961. See A. Piñeiro "Alejo Carpentier: todo en la danza le fue cercano," 42-43. ${ }^{41}$ A. Carpentier, La música en Cuba (Mexico City: Fondo de Cultura Económica, 1946), 236, 252.

${ }^{42}$ Citation from the English edition. A. Carpentier, Music in Cuba, trans. A. West-Duran (Minneapolis: Univ. of Minnesota Press, 2001), 273.

${ }^{43}$ A. Carpentier, "La evolución estética de los Ballets Rusos," in Social vol. 14, no. 4 (April 4, 1929), 37-39.

${ }^{44}$ A. Carpentier, "Las enseñanzas de Satie" and "Grandeza y decadencia del cubismo." See also, A. Carpentier, "Cocteau y sus teorías sobre el teatro"; "Jean Cocteau y la estética del ambiente"; "El arte múltiple de Picasso"; "Los dibujos de Jean Cocteau," in Chic vol. 15, no. 126 (February 1926), 16-17; and "Erick Satie, profeta y renovador," in Social vol. 12, no. 9 (September 1927), 28, 88.

${ }^{45}$ The typed text, in the holdings of the Fundación Alejo Carpentier, lacks indication about its date and publication outlet. Its tone, similar to that of articles from 1924 to 1926 in which Carpentier's discussion of avant-garde art is well informed but still tentative, allows dating it as one of those early texts. A. Carpentier, "El teatro futurista," file MPF5, No. 1-3, Fundación Alejo Carpentier.

${ }^{46}$ Guillaume Apollinaire authored the program notes upon witnessing rehearsals of the ballet. See the appendix with his text in D. Rothschild, Picasso's "Parade": From Street to Stage (New York: The Drawing Center, 1991), 26768.

${ }^{47}$ D. Rothschild, Picasso's "Parade”: From Street to Stage.

${ }^{48}$ For instance, Les Ballets Suédois's Skating Rink (1922) depicted the buzz of a contemporary city, with workers and fashionable characters sharing the stage. Another example was American-themed Within the Quota (1923), in which the present was vividly captured in Cole Porter's jazz score and Gerald Murphy's design for the backdrop-a blown-up newspaper's front page with headlines about the sale of a skyscraper, the flight of a new airplane model, and a police raid of a speakeasy. E. Näslund, "The Ballets Suédois and Its Modernist Concept," in The Cambridge Companion to Ballet, ed. M. Kant (Cambridge: Cambridge Univ. Press, 2007), 204-06. 
${ }^{49}$ Capitals in the original. Cocteau intended the managers to verbally deliver these lines, but in its final version the ballet did not include the spoken word. The essence of the libretto was conveyed through the music, dance and visual designs. D. Rothschild, Picasso's "Parade": From Street to Stage, 76-81.

${ }^{50}$ St. Lazarus is identified with the orisha Babalú Ayé in Cuban santería.

${ }^{51}$ One instance of this was Carpentier's lecture, in collaboration with Cuban composer Moisés Simons, at the Club du Foubourg, Paris, in 1932. See A Carpentier, "La consagración de nuestros ritmos," in Carteles (Havana) vol. 18, no. 15 , April 10, 1932, 20, 50, 54.

52 A. Carpentier, "Batouala - R. Maran," in La Discusión, 21 Jan. 1923, 5; reproduced in Crónicas caribeñas (Havana: Letras Cubanas, 2012), 31-34.

${ }^{53}$ F. Tobing Rony, The Third Eye: Race, Cinema, and Ethnographic Spectacle (Durham: Duke Univ. Press, 1996), $82-85,239$.

${ }^{54}$ F. Tobing Rony, The Third Eye: Race, Cinema, and Ethnographic Spectacle, 33, 47-49, 162.

${ }^{55}$ J. Borge, Latin American Writers and the Rise of Hollywood Cinema (New York: Routledge, 2008), 49-50.

${ }^{56}$ G. Mistral, "La película enemiga," in El Mercurio (Santiago), June 6, 1926, 5, reproduced in J. Borge, Avances de Hollywood: crítica cinematográfica en Latinoamérica, 1915-1945 (Rosario: Beatriz Viterbo, 2005), 105-09.

${ }^{57}$ A. Carpentier, Recuento de moradas, sections no. 14 and 15.

${ }^{58}$ Carpentier indicates the title of the documentary in Spanish as Indios, hermanos mios, and identifies the filmmaker by her nom de plume, Tytaina. A. Carpentier, "México, según una película europea," in Carteles, September 6, 1931, reproduced in Obras completas vol. 8 (Mexico: Siglo XXI, 1985), 386-90.

${ }^{59}$ Surprisingly, Carpentier does not indicate the title of the film nor the names of its producers. Considering the year of the review, Carpentier might have referred to Africa Speaks (1930), shot during US explorer Paul Hoefler's expedition to Central Africa in 1928-29. A. Carpentier, "Leyes del Africa," in Carteles vol. 17, no. 43, 27 Dec. 1931, 46-47, 50.

${ }^{60}$ F. Tobing Rony, The Third Eye: Race, Cinema, and Ethnographic Spectacle, 27, 94.

${ }^{61}$ Vicky Unruh, Latin American Vanguards, 66.

${ }^{62}$ Additionally, the Afro-Cuban performers' opposition to the Business Man brings to mind the stories of Native Americans who in the United States had violently confronted photographers and moviemakers who tried to capture them in camera. Some Native Americans blocked the view of the cameras, threw rocks at the devices, destroyed them, or chased the individuals who had managed to record any footage. F. Tobing Rony, The Third Eye: Race, Cinema, and Ethnographic Spectacle, 239-40.

${ }^{63}$ A contemporary restaging of this title by the Kirov Ballet is part of the program in The Kirov Celebrates Nijinsky, DVD (West Long Branch, NJ: Kultur, 2002).

${ }^{64}$ A. Carpentier, "La evolución estética de los Ballets Rusos."

${ }^{65}$ L. Tomé, "Envisioning a Cuban Ballet: Afrocubanismo, Nationalism and Political Commentary in Alejo Carpentier and Amadeo Roldán's La rebambaramba."

${ }^{66}$ As a Cuban working in the European medium of classical music, Roldán critically assessed his position in an international context with pre-established notions of center and periphery. He realized that, for Latin American artists, working with the elements of local folklore was double-edged. It allowed them, on the one hand, to articulate original national languages that set them apart from the European tradition. On the other hand, to patronizing European eyes it reinforced the role of Latin Americans as purveyors of the exotic, in a subordinate position of alterity within coloniality's cultural hierarchy. A. Roldán, "The Artistic Position of the American Composer," in American composers on American music, ed. H. Cowell (Stanford: Stanford Univ. Press 1933), 175-77.

${ }^{67}$ Vicky Unruh, Latin American Vanguards, 21-23, 36.

${ }^{68}$ L. Garafola, The Making of Ballet Modernism, 26

${ }^{69}$ Metatheatricality, as Unruh explains, makes theater the ideal reflexive medium for "art to talk about art." V. Unruh, Latin American Vanguards, 173. 
${ }^{70}$ See A. Carpentier, "Panorama de la música en Cuba: la música contemporánea," in Revista Musical Chilena (December 1947), reprinted in Ese músico que llevo dentro vol. 3 (Havana: Letras Cubanas, 1980), 272-84; and A. Carpentier, "Ordenado, disciplinado, trabajador y consciente," 51, and La música en Cuba, 236.

71 The publication of Malinowski's Argonauts of the Western Pacific in 1922 and Mauss's creation of the Institut d'Ethnologie in Paris in 1925 stand as landmark events in the professionalization of ethnographic fieldwork.

${ }^{72}$ A. Carpentier, La música en Cuba, 244; "El recuerdo de Amadeo Roldán," 423; "Los Cuentos negros de Lydia Cabrera," in Carteles, October 11, 1936, 40, reproduced in Crónicas caribeñas, 84-89; "El monte," in El Nacional (Caracas), March 9, 1955, reproduced in Crónicas caribeñas, 267-69; Tientos y diferencias (Mexico City: Univ. Nacional Autónoma de México, 1964), 12; and R. Márquez, "Uno de los valores musicales de nuestra América," in Amadeo Roldán: Testimonios, 120-21.

${ }^{73}$ A. Carpentier, "Lettre des Antilles," in Bifur (Paris), September 3, 1929, 91-105; and "Images et Prières Nègres," in Le Phare de Neuilly (Paris) no. 1 (1933), 41- 50.

${ }^{74}$ A. Birkenmaier, Alejo Carpentier y la Cultura del Surrealismo en América Latina; and E. Maguire, Racial Experiments in Cuban Literature and Ethnography.

75 J. Clifford, “On Ethnographic Surrealism," in Comparative Studies in Society and History vol. 23, no. 4 (1981), 548.

${ }^{76}$ A. Carpentier, "El monte."

${ }^{77}$ E. Maguire, Racial Experiments in Cuban Literature and Ethnography, 16-21.

78 A. Carpentier, "Lettre des Antilles"; "Images et Prières Nègres"; "La musique cubaine," in Documents (Paris) no. 6 (1929), 324-27; and “Cuban Magic," in Transition (New York) no. 19/20 (1930), 384-90.

${ }^{79}$ A. Birkenmaier, Alejo Carpentier y la Cultura del Surrealismo en América Latina, 55-79.

${ }^{80}$ T. F. Anderson, Carnival and National Identity in the Poetry of Afrocubanismo, 49-78.

${ }^{81}$ A. Carpentier, La música en Cuba, 225-26, 231-32.

${ }^{82}$ A. Carpentier, Tientos y diferencias, 12-13.

${ }^{83}$ A. Carpentier, "Un ballet afrocubano," and preface to Écue-Yamba-Ó (Havana: Letras Cubanas, 2012 ), 45.

${ }^{84}$ L. Cabrera, "Ritual y símbolos de la iniciación en la sociedad secreta Abakuá," in Journal de la Société des Américanistes vol. 58 (1969), 139-71.

${ }^{85}$ Such divergences could also be attributed to variations in the performance of the ritual over time and across different Abakuá groups, as acknowledged by Cabrera.

${ }^{86}$ I borrow the label "research-to-performance” from VéVé Clark, who applies it to Dunham's work. For analyses of Dunham's and Hurston's dance ethnography, see V. A. Clark, "Performing the Memory of Difference in AfroCaribbean Dance: Katherine Dunham's Choreography, 1938-1987," in History and Memory in African-American Culture, ed. G. Fabris and R. O’Meally (New York: Oxford Univ. Press, 1994), 188-204; and A. Kraut, Choreographing the Folk: The Dance Stagings of Zora Neale Hurston (Minneapolis: Univ. of Minnesota Press, 2008).

${ }^{87}$ While Hurston and Dunham integrated Caribbean dancers in their productions, they also worked with performers from the US.

${ }^{88}$ Conjunto de Danza Moderna, Auto sacramental, Suite Yoruba, El milagro de anaquillé, Concerto grosso, La rebambaramba.

${ }^{89}$ A. Kraut, Choreographing the Folk: The Dance Stagings of Zora Neale Hurston.

${ }^{90}$ E. Maguire, Racial Experiments in Cuban Literature and Ethnography, 47, 53.

${ }^{91}$ A. Carpentier, "Images et Prières Nègres," 42.

92 A. Carpentier, "El recuerdo de Amadeo Roldán," 423-24.

93 The emphasis is mine. Carpentier's various observations, while under-elaborated, support the notion that those ethnographers working within afrocubanismo in the late 1920s were self-conscious about the racial and social hierarchies mediating their engagement with the Afro-Cuban community, even if the lack of references to it in their texts from the period suggests the opposite. A. Carpentier, La música en Cuba, 225-26. 
${ }^{94}$ Marinello categorized Carpentier as a "Franco-Cuban writer" who spoke with "an irreducible Parisian accent" and was "taken for a foreigner in Havana." J. Marinello, Literatura hispanoamericana: hombres, meditaciones (Mexico: Ediciones de la Univ. Nacional de México, 1937), 168, 171.

${ }^{95}$ Z. Gómez, Amadeo Roldán (Havana: Arte y Literatura, 1977), 22-28.

${ }^{96}$ G. W. Stocking, Victorian Anthropology (New York: Free Press, 1987), 78-109.

${ }^{97}$ To be sure, anthropology was not a monolithic field in the nineteenth century. I refer here to trends that were synergetic with dominant ideologies of racism and colonialism, but, as Marvin Harris demonstrates, nineteenthcentury anthropologists developed diverging theories of race and, as a result of them, differing positions on the ethics of slavery and colonialism. M. Harris, The Rise of Anthropological Theory: A History of Theories of Culture (New York: Altamira Press, 2001), 80-141.

${ }^{98}$ J. D. Moore, Visions of Culture: an Introduction to Anthropological Theories and Theorists (Walnut Creek: Altamira, 2009), 30-41. 